\title{
Investment and Instability
}

By: Nauros F. Campos and Jeffrey B. Nugent

Working Paper Number 337

May 2000 


\title{
INVESTMENT AND INSTABILITY
}

\author{
by Nauro F. Campos and Jeffrey B. Nugent
}

\section{Executive Summary}

Socio-political instability is generally thought of as disruptive of production, therefore increasing uncertainty in the economy. By doing so, it undermines the incentives for the accumulation of physical capital and reduces the rate of economic growth. This is not only strikingly intuitive, but it is also a hypothesis that has been repeatedly confirmed in recent econometric studies. Surprisingly, however, a number of theoretical contributions from the investment literature have recently highlighted the conditions under which uncertainty has a positive effect on investment. Such a rare event in economics (a broad empirical consensus coupled with wide theoretical disagreement) calls for, inter alia, a re-examination of the evidence and, in particular, for a closer look at what this empirical literature has been leaving aside. One such overlooked issue is the existence and direction of a causal relationship between SPI and the accumulation of physical capital. That is the objective of this paper.

There are two other motives for the study. First, although the negative relationship between SPI and economic growth has been elevated to the status of a "stylized fact," the empirical studies on which it is based have been heavily criticized for ad hoc selection of explanatory or control variables, insufficient sensitivity analysis and failure to investigate the direction of causality. Second, in finding no evidence of a causal relationship between SPI and growth rates of per capita GDP, a previous study indicated that the relationship could be an indirect one operating mainly through investment.

The objective of this paper is to investigate the existence of a causal relationship between SPI and investment. To do so, we construct an index of SPI (based on the number of political assassinations, revolutions and coups $d^{\prime} E t a t$ ) for non-overlapping five-year periods between 1960 and 1995 for 98 developing countries. We use the Granger causality framework and report Anderson-Hsiao-Arellano instrumental variable estimates.

Our main conclusion is that, for the full sample, there is indeed a (robust) causal relationship going from SPI to the rate of investment, and it is positive. In other words, an increase in instability Granger causes an increase in investment. We identify three theoretical frameworks that are compatible with this result, arguing respectively that: SPI delays investment, that SPI destroys at least partly the capital stock, and that SPI causes changes in government and in government policies that are beneficial in the long run. 


\title{
INVESTMENT AND INSTABILITY*
}

\author{
Nauro F. Campos \\ CERGE-EI, Charles University, \\ Centre for Economic Policy Research \\ (CEPR), and William Davidson Institute at \\ the University of Michigan
}

\author{
Jeffrey B. Nugent \\ Department of Economics \\ University of Southern California
}

This version: May 2000

\begin{abstract}
Although recent research has repeatedly found a negative association between investment and political instability, the existence and direction of causality between these two variables has not yet been investigated. This paper empirically tests for a causal and negative longrun relationship between political instability and investment. It finds that there is a robust causal relation from instability to investment, and that it is positive. In other words, an increase in political instability Granger causes an increase in investment. We identify three different theories that can explain this result.
\end{abstract}

Keywords: political instability, aggregate investment, Granger causality.

JEL classification: O40, E23, D72.

* We thank Abla Abdel-Latif, Yi Feng, Randall Filer, Dipak Gupta, Steven Helfand, Cheng Hsiao, Christian Morrisson, Lant Pritchett, James Robinson, Luis Serven, two anonymous referees and seminar participants at the Universities of Bonn, Namur, Toronto, York, Stockholm School of Economics, CERGE-EI, and LACEA (Bogota), WEA (Seattle) and EEA (Berlin) meetings for valuable comments on previous versions of this paper. Alacritous research assistance was provided by Aurelijus Dabusinskas and Rodica Cnobloch. The usual disclaimer applies. The data set used in this paper is available from the authors upon request, and it is also available on-line as http://home.cerge.cuni.cz/ncampost/gispi.txt.

Nauro F. Campos, CERGE-EI, P.O. Box 882, 11121 Prague 1, Czech Republic. E-mail: nauro.campos@cerge.cuni.cz.

Jeffrey B. Nugent, Department of Economics, University of Southern California, Los Angeles, CA 90089-0253, USA. E-mail: nugent@ rcf.usc.edu 


\section{Introduction}

Socio-political instability (hereafter, SPI) disrupts production and increases uncertainty in the economy. By doing so, it undermines the incentives for the accumulation of physical capital and reduces the rate of economic growth. This is not only strikingly intuitive, but it is also a hypothesis that has been repeatedly confirmed in recent econometric studies. ${ }^{1}$ Surprisingly, however, a number of theoretical contributions from the investment literature have recently highlighted the conditions under which uncertainty has a positive effect on investment. ${ }^{2}$ Such a rare event in economics (a broad empirical consensus coupled with wide theoretical disagreement) calls for, inter alia, a re-examination of the evidence and, in particular, for a closer look at what this empirical literature has been leaving aside. One such overlooked issue is the existence and direction of a causal relationship between SPI and the accumulation of physical capital. That is the objective of this paper.

There are two other motives for the study. First, although the negative relationship between SPI and economic growth has been elevated to the status of a "stylized fact,"3 the empirical studies on which it is based have been heavily criticized for ad hoc selection of explanatory or control variables, insufficient sensitivity analysis and failure to investigate the direction of causality. ${ }^{4}$ Second, in finding no evidence of a causal relationship between SPI

\footnotetext{
${ }^{1}$ See, among others, Gupta (1990), Londregan and Poole (1992), Perrotti (1994), Alesina, Ozler, Roubini and Swagel (1996), Alesina and Perrotti (1996), and Ades and Chua (1997).

${ }^{2}$ See, among others, Caballero (1991), Dixit and Pindyck (1994), and Abel and Eberly (1999). For an excellent survey, see Serven (1997). In contrast, it should be noted that the theoretical literature on SPI is still at a very early stage. On the latter, see, e.g., Robinson (1994) and Benhabib and Rustichini (1996).

${ }^{3}$ Distilling the lessons from this literature, Mankiw lists among its robust findings that "political instability, as measured by the frequency of revolutions, coups, or wars, is negatively associated with growth" $(1995,302)$. Another assessment of what has been learned from such studies is the following "stylized fact" from Persson and Tabellini's chapter for the Handbook of Macroeconomics (1999): "Political instability, as measured by more frequent regime changes, or political unrest and violence, is significantly and negatively correlated with growth in cross-country data".

${ }^{4}$ Durlauf and Quah summarize this literature and find that "in addition to the four variables suggested by the augmented Solow-Swan model (initial income and the rates of human capital investment, physical capital investment, and population growth), [different studies have used a total of] 36 different categories of variables and 87 specific examples" $(1998,45)$.
} 
and growth rates of per capita GDP, Campos and Nugent (1999) suspected that the relationship could be an indirect one operating mainly through investment.

The objective of this paper is to investigate the existence of a causal relationship between SPI and investment. To do so, we construct an index of SPI (based on the number of political assassinations, revolutions and coups d'Etat) for non-overlapping five-year periods between 1960 and 1995 for 98 developing countries. We use the Granger causality framework and report Anderson-Hsiao-Arellano instrumental variable estimates.

Our main conclusion is that, for the full sample, there is indeed a (robust) causal relationship going from SPI to the rate of investment, and it is positive. In other words, an increase in instability Granger causes an increase in investment. We argue that three reasons may explain this result: that SPI delays investment, that SPI destroys at least partly the capital stock, and that SPI causes changes in government and in government policies that are beneficial in the long run. ${ }^{5}$

The paper is organized as follows. In the next section (section II) we discuss methodological and data issues. In section III we present our Granger causality results and, in section IV, subject them to various sensitivity analyses. Section V presents our major conclusions and suggestions for further research.

\section{Data and methodology}

This section has two objectives. The first is to present the data used to construct our SPI index. The second is to discuss the conceptual and econometric advantages (as well as the limitations) of the Granger causality framework.

5 Formalizations of these three explanations can be found in Abel and Eberly (1999), Hirshleifer (1987), and Robinson and Acemoglu (forthcoming), respectively. 
For our measure of SPI, we wish to be as consistent as possible with the other studies in this field. ${ }^{6}$ Hence, we draw upon three indicators: number of political assassinations, revolutions and successful coups d'Etat. $^{7}$ The first, measured as the yearly number of assassinations per million people, is especially important because it captures a magnitude dimension that is largely missing from the other (frequency) measures.

Studies on this topic often choose a cross-sectional design based on long, say 25 -year, periods. This is not only far too long a period for capturing instability, but also a clear impediment to investigating causality. On the other hand, annual data would seem too short in duration to reflect underlying factors other than mere productive time lost due to the disruptive influences themselves. For these reasons, in this study we settle on five-year, nonoverlapping periods, where the observations on SPI are the averages over each five-year interval.

In accordance with most of the literature, we use the method of principal components to construct our SPI index. We believe this method is best because it minimizes the inherent arbitrariness in the aggregation. For our index of SPI, the weights resulting from this procedure are 0.3162 for assassinations, 0.6909 for revolutions, and 0.6502 for coups.

The data on investment rates are the average share of investment in GDP, by five-year period and by country, from Summers and Heston (1994). For SPI and investment, time series data covering the period 1960-1995 are collected for an unbalanced panel of 98 developing countries. ${ }^{8}$ Included are 14 countries from Asia, 21 from Latin America, 17 from the Middle East and North Africa and 46 from Sub-Sahara Africa. Table 1 shows basic statistics and correlation matrix.

\footnotetext{
${ }^{6}$ See footnote 1.

${ }^{7}$ The data source is Barro and Lee (1993).

${ }^{8}$ The reason for choosing an unbalanced panel was to keep the exercise as comparable to the rest of the literature as possible. The sample we use differs from other studies' by very few countries.
} 


\section{INSERT TABLE 1 ABOUT HERE}

As it can be seen in Equation (1), using the data and sample described above we are able to replicate the negative (and statistically significant) contemporaneous relationship between SPI and investment found in most of the literature. ${ }^{9}$ Yet we understand these results as suggesting only association, and hence as being rather far from revealing anything useful about the existence and direction of a causal relationship.

$$
\begin{aligned}
& \text { Investment }=13.78 \text { Constant }-1.17 \quad \text { SPI } \quad \text { Adjusted R-squared }=.031 \\
& \text { (36.83) } \quad(-3.74) \quad \text { Number of observations }=414
\end{aligned}
$$

These are Ordinary Least Squares estimates, with t-statistics in parentheses.

We selected the Granger-causality framework to investigate the existence and direction of a causal relationship between socio-political instability (SPI), on the one hand, and the accumulation of physical capital, on the other. This framework has endured the test of time because of its elegance and strong intuitive appeal: the notion that an event in the future cannot cause one in the past. ${ }^{10}$ Consider two time series, $x_{t}$ and $y_{t}$. Series $x_{t}$ is said to Granger-

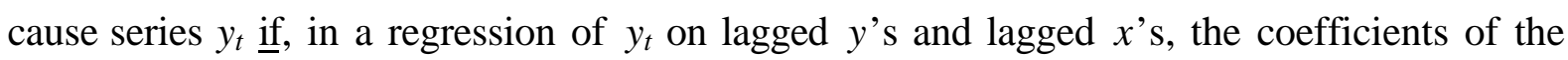
lagged $x$ 's are jointly significantly different from zero.

\footnotetext{
${ }^{9}$ In our OLS regressions of investment on (contemporaneous) SPI, the coefficients on the latter are all negative and statistically significant at the 10 percent level, for the sample as a whole (above) as well as for the four separate regions considered below, with the exception of Latin America. Notice that the addition of country dummies to equation (1) does not alter the conclusions: the coefficient on political instability is still negative and statistically significant (at the 1 percent level). Yet, the size of the coefficient on SPI changes (to -.59) and the adjusted R-squared increases (to .724).

${ }^{10}$ Granger remarks that "causation is a non-symmetric relationship, and there are various ways in which asymmetry can be introduced, the most important of which are controllability, a relevant theory, outside knowledge, and temporal priority" $(1987,49$.$) For discussion see, e.g., Hsiao (1979),$ and Zellner (1989).
} 
There are two critical issues that have to be addressed in conducting Granger causality tests. ${ }^{11}$ The first concerns the length and frequency of the time lags. On their length, Granger admonishes that "using data measured over intervals much wider than actual causal lags can also destroy causal interpretation" (Granger, 1987, 49). The use of five-year periods is short enough to allow us to investigate the effects of lagged variables and hence to undertake proper (Granger) causality tests, and yet is also long enough to be meaningful for studying the long-run effects of SPI on investment, and vice versa. As for their frequency, there are a number of tests to determine the "optimal number of lags," but because ours is a short panel we used a grid procedure to evaluate the robustness of the results presented below. ${ }^{12}$

The second issue to be dealt with lies in the information set. The Granger test depends on the assumption that the cause contains unique information about the effect, in the sense that it is exhaustive and not available elsewhere. If the information set underlying the test is composed solely of two series, both of which may be affected by a third variable, the test can be rendered useless. ${ }^{13}$ In what follows, we present Granger causality results that are unaffected after enlarged by variables that could potentially play this disruptive role.

Finally, we must attend to the econometric issue that arises from the inclusion on the right-hand side of the (lagged) dependent variable, referred to in the econometric literature as the dynamic panel problem: unless the time dimension of the panel is very large, parameter estimates will be inconsistent and biased. ${ }^{14}$ While the best solution to this problem is still an object of debate in the econometrics literature, ${ }^{15}$ in one of the few studies focusing on "short and wide" panels (like ours), Kiviet finds that the instrumental variable approach pioneered

\footnotetext{
${ }^{11}$ We do not know of other studies that use the Granger framework in this context. The closest paper to ours is Blomstrom, Lipsey and Zejan (1996).

${ }^{12}$ We tried two lags, instead of one as reported throughout the paper. The conclusions are unaffected.

${ }^{13}$ See Harvey for a discussion of this issue (1990).

${ }^{14}$ For discussion see, e.g., Hsiao (1986), Sevestre and Trognon (1992), and Baltagi (1995).

${ }^{15}$ See, among others, Holtz-Eakin et al. (1988), Arellano and Bond (1991), Kiviet (1995), and Judson and Owen (1999).
} 
by Anderson and Hsiao (1982) performs as well as any other alternative. On this basis, we use this method which requires first-differencing all variables and using second lag differences as instruments. However, we also follow Arellano (1989)'s recommendation by using the twice lagged levels instead of the twice-lagged first-differences as instruments and in Section IV we show that the results are robust to the use of alternative estimators.

\section{Empirical results}

We present the results obtained for the causality patterns between SPI and investment in Tables 2 and 3. ${ }^{16}$ In Table 2 we ask whether SPI Granger causes investment. For our complete sample of 98 developing countries there is indeed such a causal relationship as indicated by the statistical significance of the effect of the lagged SPI term on the investment rate for the current period. Strikingly, it shows that the relationship is positive rather than negative. While, as noted above, this is not inconsistent with theory —which is essentially ambiguous on the sign of the relationship — it is certainly inconsistent with the vast majority of empirical studies to date. Although the coefficients of the lagged SPI term are no longer significant in the regional sub-samples, they remain consistently positive and do not oscillate very far from the value of 0.5 obtained for the full sample.

\section{INSERT TABLE 2 ABOUT HERE}

In Table 3 we turn to the reverse question, that is, to whether investment Granger causes SPI. In this case, there is clearly no causal relationship in either the full sample or any

\footnotetext{
${ }^{16}$ Throughout the paper, we use the term " $\mathrm{x}$ Granger causes $\mathrm{y}$ " as an abbreviation for "past $\mathrm{x}$ values show a statistically significant effect on current values of y, given the past history of y."
} 
of the regions. The coefficient is essentially zero for the full sample and is between a positive 0.053 and a negative 0.01 in the sub-regions.

\section{INSERT TABLE 3 ABOUT HERE}

In sum, the main result of this exercise is that there is a Granger causality relationship going from SPI to investment, and it is positive. This obtains for our full sample, but not for any of the four regional sub-samples. Although one could easily blame this discrepancy on the smaller number of observations (in each region), there may be other explanations. Since there are broad similarities among regions of developing countries but also very considerable heterogeneity in institutional and other background characteristics among countries of each region, it would seem quite plausible that the time lags needed for the relationship to change from negative (as in the contemporary relationship between SPI and investment) to positive when SPI is lagged could well vary from one country to another within a given region. ${ }^{17}$ Before exploring further, it is imperative to provide reasonable assurance that these results are robust. This is the objective of the next section.

\section{Sensitivity analysis}

The most critical issue in applying the Granger framework concerns the content of the information set. In particular, the issue revolves around whether omitted variables might exist that could affect both investment rates and SPI, thereby giving rise to potentially serious

\footnotetext{
${ }^{17}$ It would be important to investigate under which lag length a causal relationship will appear (that is, whether using one, two, three or four-year lag lengths would change our conclusions). Gupta (1990) has annual series for a similar SPI index but only until 1982. He also mentioned (personal communication) that the updating of these series (until 1995) is not yet ready. We thus have to leave this important exercise for future work.
} 
biases in Granger causality results. ${ }^{18}$ The most natural candidate for such an omitted variable is the level of real per capita income. In Tables 4 and 5, therefore, we wish to evaluate how and to what extent including the level of real GDP per capita would affect the results of the causality tests reported above. More specifically, our hypothesis is that, in a given country, both the level of SPI and the investment rate would be negatively related to the (previously) omitted level of income per capita. Hence, we might expect to find negative effects of levels of per capita income on both investment and SPI.

\section{INSERT TABLE 4 ABOUT HERE}

From the results reported in Tables 4 and 5 it can clearly be seen that the effects of the level of GDP per capita term are generally negative. They are, however, not statistically significant. The case that comes closest to becoming statistically significant is the effect of initial income in the equation for investment for the Latin America sub-sample in Table 5 where this coefficient is significant at the 10 percent level.

\section{INSERT TABLE 5 ABOUT HERE}

Of greater importance, however, is the fact that the inclusion of this variable has little effect on the results of the causality tests. There is still, in Table 5, no causality going from

\footnotetext{
${ }^{18}$ Although we only report results using the level of income per capita to deal with the issue of the information set, the results presented in the previous section were subjected to a number of other sensitivity tests. First, the results are not affected by using (instead of level of per capita income) the rate of population growth or the growth rate of the country's main trade partners (we thank an anonymous referee for these suggestions). Second, the results remain unchanged if we include two lags, instead of one as reported throughout. Third, our conclusions do not change if instead of the Anderson-Hsiao-Arellano estimator, we report OLS (levels), OLS (first-differences), the AndersonHsiao estimator, the one-step GMM estimator proposed by Arellano and Bond (1991), the two-step GMM estimator proposed by Arellano and Bond (1991), and the GMM estimator proposed by Ahn
} 
investment rates to SPI as shown (for the regions), and there is still a causal relation for the full sample going from SPI to investment. Indeed, the size of the coefficient and its level of significance are slightly increased by the inclusion of this control. Similarly, there is a slight increase in the coefficients of the lagged SPI term in most of the sub-samples. Once again, and still in contrast with much of the existing empirical literature on the relation between SPI and investment, the causal relationship is positive. Because we can only speculate about the possible reasons for this result, we leave these speculations for the next section.

\section{Conclusions}

The objective of this paper was to investigate the existence (and direction) of a causal relationship between SPI and investment. We construct an index of SPI (based on the number of political assassinations, revolutions and successful coups d'Etat) for non-overlapping fiveyear periods between 1960 and 1995 for 98 developing countries. We use the Granger causality framework with Anderson-Hsiao-Arellano instrumental variable estimates. We find that the evidence in support of the hypothesis that a high level of SPI can cause a decrease in the rate of investment is much weaker than generally believed. Despite verifying the negative contemporaneous relationship between SPI and the investment rate, we find evidence of a robust positive causal relationship going from SPI to the investment rate.

One interesting policy implication that can be derived from these results is that there seems to be less reason to believe that SPI, by itself, constitutes such a severe barrier to medium or long-term economic growth and investment, as has often been advocated. The negative effects seem to be limited to the short run and offset by the present finding of a

and Schmidt (1995). All these results are not reported for the sake of space, but are available from the authors upon request. 
positive effect on investment over the medium term. Certainly, the results strongly contradict the notion that lower levels of SPI should be achieved at virtually any cost. ${ }^{19}$

The findings of this paper also raise new questions that should be pursued in future research. First, in view of the fact that there could be several alternative explanations for the observed positive causal relationship between SPI and investment, it would be highly desirable to try to narrow down their range. Can this result be because SPI delays investment (Abel and Eberly, 1999)? Can it be because SPI destroys at least partly the capital stock (Hirshleifer, 1987)? Or is it because SPI causes changes in government and in government policies that are beneficial in the long run (Robinson and Acemoglu, forthcoming)? Which one of these is the most important reason? Does the relative importance of these explanations vary by region or time frame?

Second, we have seen a sharp inconsistency between the existing results, that reveal a negative contemporaneous relationship between SPI and the investment rate, and our own findings of a positive and causal relationship going from SPI to the investment rate when the observations are for non-overlapping five year periods. This raises the following question: At what frequencies and lag lengths does the relationship change from negative and non-causal to one that is positive and causal? As noted before, this is one of the most important questions we leave unanswered. As soon as reliable data are available, attention should focus on this question.

Third, there would seem to be considerable scope for efforts to identify additional omitted variables, especially those of an institutional nature, which might be related to both the SPI measure and the rate of investment. Numerous institutional variables may be relevant, like the fairness and effectiveness of the judicial system, the stability of property rights, and

\footnotetext{
${ }^{19}$ Recall that a common justification given by dictators during their first days in office is that they are needed to halt the chaos, which presumably characterized the previous regime, because the cost of this instability is the disruption of productive activities with subsequent output and welfare losses.
} 
the quality of the bureaucracy. Indeed, in a cross-sectional framework Keefer and Knack (1995) find that once these are taken into account, the negative effect of SPI on growth vanishes. Another important candidate for such an omitted variable role, following Persson and Tabellini (1992, 1994) and Alesina and Perotti (1996), might be the level of income inequality. It should be noted, however, that the data (on income distribution and institutions) for time frequencies of five years or less for these "enlargements" of our Granger tests is mostly unavailable.

Finally, considering that the current traditional measure of SPI is rather coarse (i.e., is sensitive only to major disruptions such as political assassinations, revolutions and civil wars), it might be useful to experiment with somewhat finer measures of more ordinary instances of political as well as of policy instability. By constructing such measures, one could then determine whether the results presented above still hold. 


\section{References}

Abel, A. and J. Eberly, 1999, The effects of irreversibility and uncertainty on capital accumulation, Journal of Monetary Economics 44, 339-377.

Ades, A. and H. Chua, 1997, Thy neighbor's curse: regional instability and economic growth, Journal of Economic Growth 2, 279-304.

Ahn, S. and P. Schmidt, 1995, Efficient estimation of models for dynamic panel data, Journal of Econometrics 68, 5-27.

Alesina, A., Ozler, S., Roubini, N. and P. Swagel, 1996, Political instability and economic growth, Journal of Economic Growth 1, 189-211.

Alesina, A. and R. Perotti, 1996, Income distribution, political instability, and investment, European Economic Review 40, 1203-1228.

Anderson, T. and C. Hsiao, 1982, Formulation and estimation of dynamic models using panel data, Journal of Econometrics 18, 47-82.

Arellano, M., 1989, A note on the Anderson-Hsiao estimator for panel data, Economic Letters 31, 337-341.

Arellano, M. and S. Bond, 1991, Some tests of specification for panel data: Monte Carlo evidence and an application to employment equations, Review of Economic Studies 58, 277297.

Baltagi, B., 1995, Econometric analysis of panel data (John Wiley \& Sons, New York).

Barro, R. and J. Lee, 1993, Data set for 138 countries (available by anonymous ftp from www.nber.org, at directory pub/barro.lee).

Benhabib, J. and A. Rustichini, 1996, Social conflict and growth, Journal of Economic Growth 1, 125-142.

Blomstrom, M., Lipsey, R. and M. Zejan, 1996, Is fixed investment the key to economic growth? Quarterly Journal of Economics 111, 269-276.

Caballero, R., 1991, On the sign of the investment-uncertainty relationship, American Economic Review 81, 279-288.

Campos, N. and J. Nugent, 1999, Who is afraid of political instability? Working paper 126 (CERGE-EI, Prague).

Dixit, A. and R. Pindyck, 1994, Investment under uncertainty (Princeton University Press, Princeton).

Durlauf, S. and D. Quah, 1998, The new empirics of economic growth, Discussion paper 384 (Centre for Economic Performance, London). 
Granger, C.W., 1987, Causal inference, in The New Palgrave: Econometrics (W.W. Norton, New York).

Gupta, D., 1990, The economics of political violence (Praeger, New York).

Harvey, A., 1990, The econometric analysis of time series (Phillip Allan, London).

Hirshleifer, J., 1987, Economic behaviour in adversity (University of Chicago Press, Chicago).

Holtz-Eakin, D., Newey, W. and H. Rosen, 1988, Estimating vector autoregressions with panel data, Econometrica 56, 1371-1395.

Hsiao, C., 1979, Causality tests in econometrics, Journal of Economic Dynamics and Control $1,321-346$.

Hsiao, C., 1986, Analysis of panel data (Cambridge University Press, Cambridge).

Judson, R. and A. Owen, 1999, Estimating dynamic panel data models: A guide for macroeconomists, Economic Letters 65, 9-15.

Keefer, P. and S. Knack, 1995, Institutions and economic performance: Cross-country tests using alternative institutional measures, Economics and Politics 7, 207-227.

Kiviet, J., 1995, On bias, inconsistency, and efficiency of various estimators in dynamic panel data models, Journal of Econometrics 68, 53-78.

Londregan, J. and K. Poole, 1992, The seizure of executive power and economic growth: Some additional evidence, in A.Cukierman, Z.Hercowitz and L.Leiderman, eds, Political economy, growth, and business cycles (Cambridge, MIT Press).

Mankiw, G., 1995, The growth of nations, Brookings Papers on Economic Activity 1, 275310.

Perotti, R., 1994, Income distribution and investment, European Economic Review 38, 827835.

Persson, T. and G. Tabellini, 1992, Growth, distribution, and politics, in A.Cukierman, Z.Hercowitz and L.Leiderman, eds, Political economy, growth, and business cycles (Cambridge, MIT Press).

Persson, T. and G. Tabellini, 1994, Is inequality harmful for growth? American Economic Review 84, 600-621.

Persson, T. and G. Tabellini, 1999, Political economics and macroeconomic policy, in J. Taylor and M. Woodford, eds, Handbook of Macroeconomics (North-Holland, Amsterdam).

Robinson, J., 1994, Investment and political instability, mimeo, USC. 
Robinson, J. and D. Acemoglu, forthcoming, Why did the West extended the franchise? Democracy, inequality and growth in historical perspective, Quarterly Journal of Economics.

Sevestre, P. and A. Trognon, 1992, Linear dynamic models, in L. Matyas and P.Sevestre, eds, The econometrics of panel data (Kluwer, Dordrecht).

Serven, L., 1997, Economic uncertainty and private investment: An empirical investigation, mimeo, The World Bank.

Summers, R. and A. Heston, 1994, Penn world tables, Version 5.6 (available by anonymous ftp from www.nber.org, at pub/pwt56).

Zellner, A., 1988, Causality and causal laws in economics, Journal of Econometrics 39, 7-22. 
Table 1

Basic statistics and correlation matrix

\begin{tabular}{||l|c|c|c|c|}
\hline Variable & Mean & $\begin{array}{c}\text { Standard } \\
\text { Deviation }\end{array}$ & Min & Max \\
\hline Investment & 14.50814 & 7.318093 & 1.02 & 39.5 \\
\hline SPI & -.047235 & 1.215492 & -.90764 & 4.894848 \\
\hline $\begin{array}{l}\text { Per capita } \\
\text { income }\end{array}$ & 2013.678 & 1563.445 & 322 & 7777 \\
\hline $\begin{array}{l}\text { Population } \\
\text { growth }\end{array}$ & 2.532 & .7743685 & .1490161 & 6.954178 \\
\hline $\begin{array}{l}\text { Trading partners' } \\
\text { Growth }\end{array}$ & 2.519776 & 1.286855 & -2.238912 & 6.438717 \\
\hline
\end{tabular}

Correlation matrix

\begin{tabular}{||l|c|c|c|c||}
\hline \multicolumn{1}{|c|}{ Variable } & Investment & SPI & $\begin{array}{c}\text { Per capita } \\
\text { income }\end{array}$ & $\begin{array}{c}\text { Population } \\
\text { growth }\end{array}$ \\
\hline SPI & -0.2237 & & & \\
\hline Per capita income & 0.5013 & -0.1080 & & \\
\hline Population growth & 0.0189 & -0.0665 & -0.0511 & \\
\hline $\begin{array}{l}\text { Trading partners' } \\
\text { Growth }\end{array}$ & 0.0512 & -0.0149 & -0.1583 & 0.0297 \\
\hline Note: See text for details.
\end{tabular}


Table 2.

Does SPI Granger cause investment?

(Endogenous variable is $\Delta \mathrm{INV}_{\mathrm{t}}$ )

\begin{tabular}{||l|c|c|}
\hline & $\Delta \mathrm{INV}_{\mathrm{t}-1}$ & $\Delta \mathrm{SPI}_{\mathrm{t}-1}$ \\
\hline All LDCs & $.893647 * * *$ & $.502752 * *$ \\
& $(3.62041)$ & $(2.12038)$ \\
\hline Asia & $.509661 *$ & .589710 \\
& $(1.91667)$ & $.38880)$ \\
\hline Latin America & $.985997 * * *$ & .729442 \\
& $(3.12381)$ & $.542963)$ \\
\hline Middle East \& North & .482033 & $(.753546)$ \\
Africa & $(1.46367)$ & .398886 \\
\hline Sub-Saharan Africa & $.950372 * * *$ & $(1.17682)$ \\
\hline
\end{tabular}

Notes: All variables are in first-differences $(\Delta)$; five-year averages, between 19601995, and t-statistics are in parentheses. Instrumental variables estimates shown (Anderson-Hsiao-Arellano). SPI is the measure of social and political instability described in the text, and $I N V$ is the investment as a share of GDP.

* Statistically significant at the 10 percent level.

** Statistically significant at the 5 percent level.

*** Statistically significant at the 1 percent level. 
Table 3.

Does investment Granger cause SPI?

(Endogenous variable is $\Delta \mathrm{SPI}_{\mathrm{t}}$ )

\begin{tabular}{||l|c|c|}
\hline & $\Delta$ SPI $_{\mathrm{t}-1}$ & $\Delta \mathrm{INV}_{\mathrm{t}-1}$ \\
\hline All LDCs & .179173 & .009473 \\
& $(1.60772)$ & $(.427063)$ \\
\hline Asia & .242095 & .052338 \\
& $(.721596)$ & $(.836329)$ \\
\hline Latin America & .050252 & -.006459 \\
& $(.225079)$ & $(-.127577)$ \\
\hline Middle East \& North & .188081 & .014092 \\
Africa & $(1.26888)$ & $(.427949)$ \\
\hline Sub-Saharan Africa & .216226 & -.000037 \\
& $(1.05233)$ & $(-.000973)$ \\
\hline
\end{tabular}

Notes: All variables are in first-differences $(\Delta)$; five-year averages, between 19601995, and t-statistics are in parentheses. Instrumental variables estimates shown (Anderson-Hsiao-Arellano). SPI is the measure of social and political instability described in the text, and $I N V$ is the investment as a share of GDP.

* Statistically significant at the 10 percent level.

** Statistically significant at the 5 percent level.

*** Statistically significant at the 1 percent level. 
Table 4.

Controlling for initial income, does SPI Granger cause Investment?

(Endogenous variable is $\Delta \mathrm{INV}_{\mathrm{t}}$ )

\begin{tabular}{||l|c|c|c|}
\hline & $\Delta \mathrm{INV}_{\mathrm{t}-1}$ & $\Delta \mathrm{SPI}_{\mathrm{t}-1}$ & $\Delta \mathrm{GDP0}_{\mathrm{t}-1}$ \\
\hline All LDCs & $.1 .0908^{*} * *$ & $.570358 * *$ & -.000765 \\
& $(4.02819)$ & $(2.26743)$ & $(-1.27153)$ \\
\hline Asia & .479503 & .566251 & -.000996 \\
& $(1.38807)$ & $(1.34604)$ & $(-.785538)$ \\
\hline Latin America & $.875797 * * *$ & .325820 & $-.001764 *$ \\
& $(3.12665)$ & $(.788490)$ & $(-1.90024)$ \\
\hline Middle East \& North & .591943 & .884785 & .000595 \\
Africa & $(1.15719)$ & $(1.13967)$ & $(.649242)$ \\
\hline Sub-Saharan Africa & $1.01528 * * *$ & .416341 & .000427 \\
& $(3.03117)$ & $(1.17973)$ & $(.357729)$ \\
\hline
\end{tabular}

Notes: All variables are in first-differences $(\Delta)$; five-year averages, between 1960-1995, and t-statistics are in parentheses. Instrumental variables estimates shown (AndersonHsiao-Arellano). SPI is the measure of social and political instability described in the text, GDPO is level of initial per capita income, and $I N V$ is the investment as a share of GDP.

* Statistically significant at the 10 percent level.

** Statistically significant at the 5 percent level.

*** Statistically significant at the 1 percent level. 
Table 5.

Controlling for initial income, does investment Granger cause SPI?

(Endogenous variable is $\Delta \mathrm{SPI}_{\mathrm{t}}$ )

\begin{tabular}{||l|c|c|c|}
\hline & $\Delta \mathrm{SPI}_{\mathrm{t}-1}$ & $\Delta \mathrm{INV}_{\mathrm{t}-1}$ & $\Delta \mathrm{GDPO}_{\mathrm{t}-1}$ \\
\hline All LDCs & .166307 & .013304 & -.000091 \\
& $(1.51044)$ & $(.538796)$ & $(-.535246)$ \\
\hline Asia & .313547 & .070839 & -.000274 \\
& $(.873603)$ & $(.950382)$ & $(-.497368)$ \\
\hline Latin America & .043146 & .002559 & -.000232 \\
& $(.191834)$ & $(.048111)$ & $(-.618292)$ \\
\hline Middle East \& North & .154136 & .032343 & -.000155 \\
Africa & $(.989875)$ & $(.620861)$ & $(-.717280)$ \\
\hline Sub-Saharan Africa & .177278 & -.001221 & .000097 \\
& $(.923239)$ & $(-.032562)$ & $(.246857)$ \\
\hline
\end{tabular}

Notes: All variables are in first-differences $(\Delta)$; five-year averages, between 1960-1995, and t-statistics are in parentheses. Instrumental variables estimates shown (AndersonHsiao-Arellano). SPI is the measure of social and political instability described in the text, GDPO is level of initial per capita income, and $I N V$ is the investment as a share of GDP.

* Statistically significant at the 10 percent level.

** Statistically significant at the 5 percent level.

*** Statistically significant at the 1 percent level. 


\section{APPENDIX TABLES \\ (FOR THE SAKE OF SPACE, THE AUTHORS FEEL THESE APPENDIX TABLES SHOULD NOT BE PUBLISHED)}

\begin{tabular}{|c|c|c|c|}
\hline \multicolumn{4}{|c|}{$\begin{array}{l}\text { Table A1. } \\
\text { Controlling for POPULATION GROWTH, } \\
\text { does SPI Granger cause Investment? } \\
\left(\text { Endogenous variable is } \Delta \mathrm{INV}_{\mathrm{t}}\right)\end{array}$} \\
\hline & $\Delta \mathrm{INV}_{\mathrm{t}-1}$ & $\Delta \mathrm{SPI}_{\mathrm{t}-1}$ & $\Delta \mathrm{POP}_{\mathrm{t}-1}$ \\
\hline All LDCs & $\begin{array}{l}.870356 * * * \\
(3.45445)\end{array}$ & $\begin{array}{l}.495160 * * \\
(2.11091)\end{array}$ & $\begin{array}{l}.022379 \\
(.056591)\end{array}$ \\
\hline Asia & $\begin{array}{l}.628421^{*} \\
(1.78597)\end{array}$ & $\begin{array}{c}.719482 \\
(1.48854)\end{array}$ & $\begin{array}{c}1.65062 \\
(.860579)\end{array}$ \\
\hline Latin America & $\begin{array}{l}.988830 * * * \\
(3.05249)\end{array}$ & $\begin{array}{l}.328082 \\
(.754105)\end{array}$ & $\begin{array}{l}-3.25241^{*} \\
(-1.79404)\end{array}$ \\
\hline $\begin{array}{l}\text { Middle East \& North } \\
\text { Africa }\end{array}$ & $\begin{array}{c}.429354 \\
(1.33768)\end{array}$ & $\begin{array}{l}.608828 \\
(.872319)\end{array}$ & $\begin{array}{c}.817088 \\
(1.50307)\end{array}$ \\
\hline Sub-Saharan Africa & $\begin{array}{l}.977459 * * * \\
(2.81548)\end{array}$ & $\begin{array}{r}.408573 \\
(1.18540)\end{array}$ & $\begin{array}{c}-.578716 \\
(-.865717)\end{array}$ \\
\hline \multicolumn{4}{|c|}{$\begin{array}{l}\text { Notes: All variables are in first-differences }(\Delta) \text {; five-year averages, between } 1960-1995 \text {, } \\
\text { and t-statistics are in parentheses. Instrumental variables estimates shown (Anderson- } \\
\text { Hsiao-Arellano). SPI is the measure of social and political instability described in the } \\
\text { text, and } I N V \text { is the investment as a share of GDP. } \\
* \text { Statistically significant at the } 10 \text { percent level. } \\
\text { ** Statistically significant at the } 5 \text { percent level. } \\
* * * \text { Statistically significant at the } 1 \text { percent level. }\end{array}$} \\
\hline
\end{tabular}




\begin{tabular}{|c|c|c|c|}
\hline \multicolumn{4}{|c|}{$\begin{array}{c}\text { Table A2. } \\
\text { Controlling for POPULATION GROWTH, } \\
\text { does investment Granger cause SPI? } \\
\left.\text { (Endogenous variable is } \Delta \text { SPI }_{t}\right)\end{array}$} \\
\hline & $\Delta \mathrm{SPI}_{\mathrm{t}-1}$ & $\Delta \mathrm{INV}_{\mathrm{t}-1}$ & $\Delta \mathrm{POP}_{\mathrm{t}-1}$ \\
\hline All LDCs & $\begin{array}{c}.178916 \\
(1.60117)\end{array}$ & $\begin{array}{l}.010280 \\
(.455738)\end{array}$ & $\begin{array}{c}-.031488 \\
(-.198264)\end{array}$ \\
\hline Asia & $\begin{array}{c}.295503 \\
(.830154) \\
\end{array}$ & $\begin{array}{c}.089502 \\
(1.24806)\end{array}$ & $\begin{array}{l}.876087 \\
(1.22090)\end{array}$ \\
\hline Latin America & $\begin{array}{r}.039254 \\
(.177791)\end{array}$ & $\begin{array}{l}.000866 \\
(.017020)\end{array}$ & $\begin{array}{r}-.535876 \\
(-1.09077)\end{array}$ \\
\hline $\begin{array}{l}\text { Middle East \& North } \\
\text { Africa }\end{array}$ & $\begin{array}{c}.217301 \\
(1.38818)\end{array}$ & $\begin{array}{r}.000630 \\
(.017839)\end{array}$ & $\begin{array}{c}.296797 \\
(1.02576)\end{array}$ \\
\hline Sub-Saharan Africa & $\begin{array}{r}.229854 \\
(1.09684)\end{array}$ & $\begin{array}{c}.004162 \\
(.105998)\end{array}$ & $\begin{array}{c}-.117832 \\
(-.503505)\end{array}$ \\
\hline \multicolumn{4}{|c|}{$\begin{array}{l}\text { Notes: All variables are in first-differences }(\Delta) \text {; five-year averages, between } 1960-1995 \text {, } \\
\text { and t-statistics are in parentheses. Instrumental variables estimates shown (Anderson- } \\
\text { Hsiao-Arellano). SPI is the measure of social and political instability described in the } \\
\text { text, and } I N V \text { is the investment as a share of GDP. } \\
* \text { Statistically significant at the } 10 \text { percent level. } \\
* * \text { Statistically significant at the } 5 \text { percent level. } \\
* * * \text { Statistically significant at the } 1 \text { percent level. }\end{array}$} \\
\hline
\end{tabular}


Table A3.

Controlling for GROWTH OF TRADING PARTNERS, does SPI Granger cause Investment?

(Endogenous variable is $\Delta \mathrm{INV}_{\mathrm{t}}$ )

\begin{tabular}{||l|c|c|c|}
\hline & $\Delta \mathrm{INV}_{\mathrm{t}-1}$ & $\Delta \mathrm{SPI}_{\mathrm{t}-1}$ & $\Delta \mathrm{GTR}_{\mathrm{t}-1}$ \\
\hline All LDCs & $.916914 * * *$ & $.494652^{* *}$ & .219434 \\
& $(3.53772)$ & $(2.10042)$ & $(.968316)$ \\
\hline Asia & .469499 & .591597 & -.001962 \\
& $(1.42426)$ & $(1.33700)$ & $(-.004770)$ \\
\hline Latin America & $.792024 * *$ & .313558 & -.748561 \\
& $(2.93741)$ & $(.782300)$ & $(-1.35130)$ \\
\hline Middle East \& North & .400863 & .573896 & $.762555^{*}$ \\
Africa & $(1.42097)$ & $(.930403)$ & $(1.68708)$ \\
\hline Sub-Saharan Africa & $1.02009 * * *$ & .362235 & .403976 \\
& $(2.89602)$ & $(1.05716)$ & $(1.08613)$ \\
\hline
\end{tabular}

Notes: All variables are in first-differences $(\Delta)$; five-year averages, between 1960-1995, and t-statistics are in parentheses. Instrumental variables estimates shown (AndersonHsiao-Arellano). SPI is the measure of social and political instability described in the text, and $I N V$ is the investment as a share of GDP.

* Statistically significant at the 10 percent level.

** Statistically significant at the 5 percent level.

$* * *$ Statistically significant at the 1 percent level. 
Table A4.

Controlling for GROWTH OF TRADING PARTNERS , does investment Granger cause SPI?

(Endogenous variable is $\Delta \mathrm{SPI}_{\mathrm{t}}$ )

\begin{tabular}{||l|c|c|c||}
\hline & $\Delta \mathrm{SPI}_{\mathrm{t}-1}$ & $\Delta \mathrm{INV}_{\mathrm{t}-1}$ & $\Delta \mathrm{GTR}_{\mathrm{t}-1}$ \\
\hline All LDCs & .165976 & .002322 & -.096486 \\
& $(1.41303)$ & $(.091289)$ & $(-.983672)$ \\
\hline Asia & .296963 & .058271 & .046298 \\
& $(.766835)$ & $(.776063)$ & $(.216719)$ \\
\hline Latin America & .031645 & -.015641 & -.240306 \\
& $(.140057)$ & $(-.302442)$ & $(-.859321)$ \\
\hline Middle East \& North & .170574 & .010323 & .091445 \\
Africa & $(1.10542)$ & $(.289720)$ & $(.536827)$ \\
\hline Sub-Saharan Africa & .257419 & -.031727 & -.293152 \\
& $(1.05863)$ & $(-.621936)$ & $(-1.43488)$ \\
\hline
\end{tabular}

Notes: All variables are in first-differences $(\Delta)$; five-year averages, between 1960-1995, and t-statistics are in parentheses. Instrumental variables estimates shown (AndersonHsiao-Arellano). SPI is the measure of social and political instability described in the text, and $I N V$ is the investment as a share of GDP.

* Statistically significant at the 10 percent level.

** Statistically significant at the 5 percent level.

*** Statistically significant at the 1 percent level. 


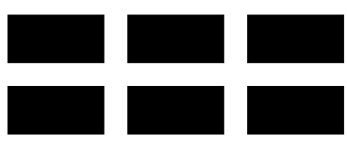

THE WILLIAM DAVIDSON INSTITUTE

AT THE UNIVERSITY OF MICHIGAN BUSINESSSCHOOL

\section{DAVIDSON INSTITUTE WORKING PAPER SERIES}

CURRENT AS OF 10/4/00

\begin{tabular}{|c|c|c|}
\hline Publication & Authors & Date of Paper \\
\hline No. 337 Investment and Instability & Nauro F. Campos and Jeffrey B. Nugent & May 2000 \\
\hline $\begin{array}{l}\text { No. } 336 \text { The Evolution of the Insurance } \\
\text { Sector in Central and Eastern Europe and } \\
\text { the former Soviet Union }\end{array}$ & Robert B.K. Pye & August 2000 \\
\hline $\begin{array}{l}\text { No. } 335 \text { Institutional Technology and the } \\
\text { Chains of Trust: Capital Markets and } \\
\text { Privatization in Russia and the Czech } \\
\text { Republic }\end{array}$ & Bruce Kogut and Andrew Spicer & August 2000 \\
\hline $\begin{array}{l}\text { No. } 334 \text { The Evolution of Market Integration } \\
\text { in Russia }\end{array}$ & Daniel Berkowitz and David N. DeJong & August 2000 \\
\hline $\begin{array}{l}\text { No. } 333 \text { Efficiency and Market Share in } \\
\text { Hungarian Corporate Sector }\end{array}$ & László Halpern and Gábor Körösi & July 2000 \\
\hline $\begin{array}{l}\text { No. } 332 \text { Search-Money-and-Barter Models of } \\
\text { Financial Stabilization }\end{array}$ & S.I. Boyarchenko and S.Z. Levendorskii & July 2000 \\
\hline $\begin{array}{l}\text { No. } 331 \text { Worker Training in a Restructuring } \\
\text { Economy: Evidence from the Russian } \\
\text { Transition }\end{array}$ & $\begin{array}{l}\text { Mark C. Berger, John S. Earle and Klara } \\
\text { Z. Sabirianova }\end{array}$ & August 2000 \\
\hline $\begin{array}{l}\text { No. 330 Economic Development in Palanpur } \\
\text { 1957-1993: A Sort of Growth }\end{array}$ & Peter Lanjouw & August 2000 \\
\hline $\begin{array}{l}\text { No. } 329 \text { Trust, Organizational Controls, } \\
\text { Knowledge Acquisition from the Foreign } \\
\text { Parents, and Performance in Vietnamese } \\
\text { International Joint Ventures }\end{array}$ & $\begin{array}{l}\text { Marjorie A. Lyles, Le Dang Doanh, and } \\
\text { Jeffrey } Q . \text { Barden }\end{array}$ & June 2000 \\
\hline $\begin{array}{l}\text { No. } 328 \text { Comparative Advertising in the } \\
\text { Global Marketplace: The Effects of Cultural } \\
\text { Orientation on Communication }\end{array}$ & $\begin{array}{l}\text { Zeynep Gürhan-Canli and Durairaj } \\
\text { Maheswaran }\end{array}$ & August 2000 \\
\hline $\begin{array}{l}\text { No. } 327 \text { Post Privatization Enterprise } \\
\text { Restructuring }\end{array}$ & Morris Bornstein & July 2000 \\
\hline No. 326 Who is Afraid of Political Instability? & Nauro F. Campos and Jeffrey B. Nugent & July 2000 \\
\hline $\begin{array}{l}\text { No. } 325 \text { Business Groups, the Financial } \\
\text { Market and Modernization }\end{array}$ & Raja Kali & June 2000 \\
\hline $\begin{array}{l}\text { No. } 324 \text { Restructuring with What Success? A } \\
\text { Case Study of Russian Firms }\end{array}$ & Susan Linz & July 2000 \\
\hline $\begin{array}{l}\text { No. } 323 \text { Priorities and Sequencing in } \\
\text { Privatization: Theory and Evidence from the } \\
\text { Czech Republic }\end{array}$ & $\begin{array}{l}\text { Nandini Gupta, John C. Ham and Jan } \\
\text { Svejnar }\end{array}$ & May 2000 \\
\hline $\begin{array}{l}\text { No. } 322 \text { Liquidity, Volatility, and Equity } \\
\text { Trading Costs Across Countries and Over } \\
\text { Time }\end{array}$ & $\begin{array}{l}\text { Ian Domowitz, Jack Glen and Ananth } \\
\text { Madhavan }\end{array}$ & March 2000 \\
\hline $\begin{array}{l}\text { No. } 321 \text { Equilibrium Wage Arrears: } \\
\text { Institutional Lock-In of Contractual Failure in } \\
\text { Russia }\end{array}$ & John S. Earle and Klara Z. Sabirianova & June 2000 \\
\hline $\begin{array}{l}\text { No. } 320 \text { Rethinking Marketing Programs for } \\
\text { Emerging Markets }\end{array}$ & Niraj Dawar and Amitava Chattopadhyay & June 2000 \\
\hline $\begin{array}{l}\text { No. } 319 \text { Public Finance and Low Equilibria in } \\
\text { Transition Economies; the Role of Institutions }\end{array}$ & Daniel Daianu and Radu Vranceanu & June 2000 \\
\hline
\end{tabular}

Working Papers are available at:

www.wdi.bus.umich.edu 


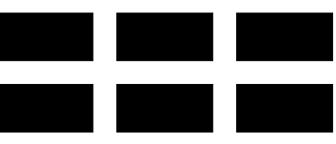

THE WILLIAM DAVIDSON INSTITUTE AT THE UNIVERSITY OF MICHIGAN BUSINESSSCHOOL

\begin{tabular}{|c|c|c|}
\hline $\begin{array}{l}\text { No. } 318 \text { Some Econometric Evidence on the } \\
\text { Effectiveness of Active Labour Market } \\
\text { Programmes in East Germany }\end{array}$ & Martin Eichler and Michael Lechner & June 2000 \\
\hline $\begin{array}{l}\text { No. } 317 \text { A Model of Russia's "Virtual } \\
\text { Economy" }\end{array}$ & R.E Ericson and B.W Ickes & May 2000 \\
\hline $\begin{array}{l}\text { No. } 316 \text { Financial Institutions, Financial } \\
\text { Contagion, and Financial Crises }\end{array}$ & Haizhou Huang and Chenggang Xu & March 2000 \\
\hline $\begin{array}{l}\text { No. } 315 \text { Privatization versus Regulation in } \\
\text { Developing Economies: The Case of West } \\
\text { African Banks }\end{array}$ & $\begin{array}{l}\text { Jean Paul Azam, Bruno Biais, and } \\
\text { Magueye Dia }\end{array}$ & February 2000 \\
\hline $\begin{array}{l}\text { No. } 314 \text { Is Life More Risky in the Open? } \\
\text { Household Risk-Coping and the Opening of } \\
\text { China's Labor Markets }\end{array}$ & John Giles & April 2000 \\
\hline $\begin{array}{l}\text { No. } 313 \text { Networks, Migration and Investment: } \\
\text { Insiders and Outsiders in Tirupur's } \\
\text { Production Cluster }\end{array}$ & Abhijit Banerjee and Kaivan Munshi & March 2000 \\
\hline $\begin{array}{l}\text { No. } 312 \text { Computational Analysis of the Impact } \\
\text { on India of the Uruguay Round and the } \\
\text { Forthcoming WTO Trade Negotiations }\end{array}$ & $\begin{array}{l}\text { Rajesh Chadha, Drusilla K. Brown, Alan } \\
\text { V. Deardorff and Robert M. Stern }\end{array}$ & March 2000 \\
\hline $\begin{array}{l}\text { No. } 311 \text { Subsidized Jobs for Unemployed } \\
\text { Workers in Slovakia }\end{array}$ & Jan. C. van Ours & May 2000 \\
\hline $\begin{array}{l}\text { No. } 310 \text { Determinants of Managerial Pay in } \\
\text { the Czech Republic }\end{array}$ & $\begin{array}{l}\text { Tor Eriksson, Jaromir Gottvald and Pavel } \\
\text { Mrazek }\end{array}$ & May 2000 \\
\hline $\begin{array}{l}\text { No. } 309 \text { The Great Human Capital } \\
\text { Reallocation: An Empirical Analysis of } \\
\text { Occupational Mobility in Transitional Russia }\end{array}$ & Klara Z. Sabirianova & May 2000 \\
\hline $\begin{array}{l}\text { No. } 308 \text { Economic Development, Legality, and } \\
\text { the Transplant Effect }\end{array}$ & $\begin{array}{l}\text { Daniel Berkowitz, Katharina Pistor, and } \\
\text { Jean-Francois Richard }\end{array}$ & February 2000 \\
\hline $\begin{array}{l}\text { No. } 307 \text { Community Participation, Teacher } \\
\text { Effort, and Educational Outcome: The Case of } \\
\text { El Salvador's EDUCO Program }\end{array}$ & Yasuyuki Sawada & November 1999 \\
\hline $\begin{array}{l}\text { No. } 306 \text { Gender Wage Gap and Segregation in } \\
\text { Late Transition }\end{array}$ & Stepan Jurajda & May 2000 \\
\hline $\begin{array}{l}\text { No. } 305 \text { The Gender Pay Gap in the } \\
\text { Transition from Communism: Some Empirical } \\
\text { Evidence }\end{array}$ & Andrew Newell and Barry Reilly & May 2000 \\
\hline $\begin{array}{l}\text { No. } 304 \text { Post-Unification Wage Growth in } \\
\text { East Germany }\end{array}$ & Jennifer Hunt & November 1998 \\
\hline $\begin{array}{l}\text { No. } 303 \text { How Does Privatization Affect } \\
\text { Workers? The Case of the Russian Mass } \\
\text { Privatization Program }\end{array}$ & Elizabeth Brainerd & May 2000 \\
\hline $\begin{array}{l}\text { No. } 302 \text { Liability for Past Environmental } \\
\text { Contamination and Privatization }\end{array}$ & Dietrich Earnhart & March 2000 \\
\hline No. 301 Varieties, Jobs and EU Enlargement & Tito Boeri and Joaquim Oliveira Martins & May 2000 \\
\hline No. 300 Employer Size Effects in Russia & Todd Idson & April 2000 \\
\hline $\begin{array}{l}\text { No. } 299 \text { Information Complements, } \\
\text { Substitutes, and Strategic Product Design }\end{array}$ & $\begin{array}{l}\text { Geoffrey G. Parker and Marshall W. Van } \\
\text { Alstyne }\end{array}$ & March 2000 \\
\hline $\begin{array}{l}\text { No. } 298 \text { Markets, Human Capital, and } \\
\text { Inequality: Evidence from Rural China }\end{array}$ & $\begin{array}{l}\text { Dwayne Benjamin, Loren Brandt, Paul } \\
\text { Glewwe, and Li Guo }\end{array}$ & May 2000 \\
\hline $\begin{array}{l}\text { No. } 297 \text { Corporate Governance in the Asian } \\
\text { Financial Crisis }\end{array}$ & $\begin{array}{l}\text { Simon Johnson, Peter Boone, Alasdair } \\
\text { Breach, and Eric Friedman }\end{array}$ & November 1999 \\
\hline
\end{tabular}

Working Papers are available at: www.wdi.bus.umich.edu 


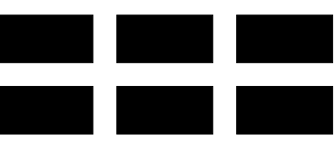

THE WILLIAM DAVIDSON INSTITUTE

AT THE UNIVERSITY OF MICHIGAN BUSINESSSCHOOL

\begin{tabular}{|c|c|c|}
\hline $\begin{array}{l}\text { No. } 296 \text { Competition and Firm Performance: } \\
\text { Lessons from Russia }\end{array}$ & J. David Brown and John S. Earle & March 2000 \\
\hline $\begin{array}{l}\text { No. } 295 \text { Wage Determination in Russia: An } \\
\text { Econometric Investigation }\end{array}$ & Peter J. Luke and Mark E. Schaffer & March 2000 \\
\hline $\begin{array}{l}\text { No. 294: Can Banks Promote Enterprise } \\
\text { Restructuring?: Evidence From a Polish } \\
\text { Bank's Experience }\end{array}$ & John P. Bonin and Bozena Leven & March 2000 \\
\hline $\begin{array}{l}\text { No. 293: Why do Governments Sell Privatised } \\
\text { Companies Abroad? }\end{array}$ & $\begin{array}{l}\text { Bernardo Bortolotti, Marcella Fantini and } \\
\text { Carlo Scarpa }\end{array}$ & March 2000 \\
\hline $\begin{array}{l}\text { No. 292: Going Public in Poland: Case-by- } \\
\text { Case Privatizations, Mass Privatization and } \\
\text { Private Sector Initial Public Offerings }\end{array}$ & Wolfgang Aussenegg & December 1999 \\
\hline $\begin{array}{l}\text { No. 291: Institutional Technology and the } \\
\text { Chains of Trust: Capital Markets and } \\
\text { Privatization in Russia and the Czech } \\
\text { Republic }\end{array}$ & Bruce Kogut and Andrew Spicer & March 1999 \\
\hline $\begin{array}{l}\text { No. 290: Banking Crises and Bank Rescues: } \\
\text { The Effect of Reputation }\end{array}$ & Jenny Corbett and Janet Mitchell & January 2000 \\
\hline $\begin{array}{l}\text { No. 289: Do Active Labor Market Policies } \\
\text { Help Unemployed Workers to Find and Keep } \\
\text { Regular Jobs? }\end{array}$ & Jan C. van Ours & February 2000 \\
\hline $\begin{array}{l}\text { No. 288: Consumption Patterns of the New } \\
\text { Elite in Zimbabwe }\end{array}$ & Russell Belk & February 2000 \\
\hline $\begin{array}{l}\text { No. 287: Barter in Transition Economies: } \\
\text { Competing Explanations Confront Ukranian } \\
\text { Data }\end{array}$ & $\begin{array}{l}\text { Dalia Marin, Daniel Kaufmann and } \\
\text { Bogdan Gorochowskij }\end{array}$ & January 2000 \\
\hline $\begin{array}{l}\text { No. 286: The Quest for Pension Reform: } \\
\text { Poland's Security through Diversity }\end{array}$ & Marek Góra and Michael Rutkowski & January 2000 \\
\hline $\begin{array}{l}\text { No. 285: Disorganization and Financial } \\
\text { Collapse }\end{array}$ & Dalia Marin and Monika Schnitzer & October 1999 \\
\hline $\begin{array}{l}\text { No. 284: Coordinating Changes in M-form } \\
\text { and U-form Organizations }\end{array}$ & $\begin{array}{l}\text { Yingyi Qian, Gérard Roland and } \\
\text { Chenggang } X u\end{array}$ & May 1999 \\
\hline $\begin{array}{l}\text { No. 283: Why Russian Workers Do Not Move: } \\
\text { Attachment of Workers Through In-Kind } \\
\text { Payments }\end{array}$ & Guido Friebel and Sergei Guriev & October 1999 \\
\hline $\begin{array}{l}\text { No. 282: Lessons From Fiascos in Russian } \\
\text { Corporate Governance }\end{array}$ & Merritt B. Fox and Michael A. Heller & October 1999 \\
\hline $\begin{array}{l}\text { No. 281: Income Distribution and Price } \\
\text { Controls: Targeting a Social Safety Net } \\
\text { During Economic Transition }\end{array}$ & Michael Alexeev and James Leitzel & March 1999 \\
\hline $\begin{array}{l}\text { No. 280: Starting Positions, Reform Speed, } \\
\text { and Economic Outcomes in Transitioning } \\
\text { Economies }\end{array}$ & William Hallagan and Zhang Jun & January 2000 \\
\hline No. 279: The Value of Prominent Directors & Yoshiro Miwa \& J. Mark Ramseyer & October 1999 \\
\hline No. 278: The System Paradigm & János Kornai & April 1998 \\
\hline $\begin{array}{l}\text { No. 277: The Developmental Consequences of } \\
\text { Foreign Direct Investment in the Transition } \\
\text { from Socialism to Capitalism: The } \\
\text { Performance of Foreign Owned Firms in } \\
\text { Hungary }\end{array}$ & Lawrence Peter King & September 1999 \\
\hline No. 276: Stability and Disorder: An & Clifford Gaddy and Barry W. Ickes & November 1999 \\
\hline
\end{tabular}

Working Papers are available at:

www.wdi.bus.umich.edu 


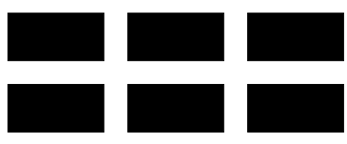

THE WILLIAM DAVIDSON INSTITUTE AT THE UNIVERSITY OF MICHIGAN BUSINESSSCHOOL

\begin{tabular}{|c|c|c|}
\hline $\begin{array}{l}\text { Evolutionary Analysis of Russia's Virtual } \\
\text { Economy }\end{array}$ & & \\
\hline $\begin{array}{l}\text { No. 275: Limiting Government Predation } \\
\text { Through Anonymous Banking: A Theory with } \\
\text { Evidence from China. }\end{array}$ & $\begin{array}{l}\text { Chong-En Bai, David D. Li, Yingyi Qian } \\
\text { and Yijiang Wang }\end{array}$ & July 1999 \\
\hline No. 274: Transition with Labour Supply & Tito Boeri & December 1999 \\
\hline $\begin{array}{l}\text { No. 273: Sectoral Restructuring and Labor } \\
\text { Mobility: A Comparative Look at the Czech } \\
\text { Republic }\end{array}$ & Vit Sorm and Katherine Terrell & November 1999 \\
\hline $\begin{array}{l}\text { No. 272: Published in: Journal of } \\
\text { Comparative Economics "Returns to Human } \\
\text { Capital Under the Communist Wage Grid and } \\
\text { During the Transition to a Market Economy" } \\
\text { Vol. 27, pp. 33-60 1999. }\end{array}$ & $\begin{array}{l}\text { Daniel Munich, Jan Svejnar and Katherine } \\
\text { Terrell }\end{array}$ & October 1999 \\
\hline $\begin{array}{l}\text { No. 271: Barter in Russia: Liquidity Shortage } \\
\text { Versus Lack of Restructuring }\end{array}$ & Sophie Brana and Mathilde Maurel & June 1999 \\
\hline $\begin{array}{l}\text { No. 270: Tests for Efficient Financial } \\
\text { Intermediation with Application to China }\end{array}$ & Albert Park and Kaja Sehrt & March 1999 \\
\hline $\begin{array}{l}\text { No. } 269 a: \text { Russian Privatization and } \\
\text { Corporate Governance: What Went Wrong? }\end{array}$ & $\begin{array}{l}\text { Bernard Black, Reinier Kraakman and } \\
\text { Anna Tarassova }\end{array}$ & May 2000 \\
\hline $\begin{array}{l}\text { No. 269: Russian Privatization and Corporate } \\
\text { Governance: What Went Wrong? }\end{array}$ & $\begin{array}{l}\text { Bernard Black, Reinier Kraakman and } \\
\text { Anna Tarassova }\end{array}$ & September 1999 \\
\hline $\begin{array}{l}\text { No. 268: Are Russians Really Ready for } \\
\text { Capitalism? }\end{array}$ & Susan Linz & September 1999 \\
\hline $\begin{array}{l}\text { No. 267: Do Stock Markets Promote } \\
\text { Economic Growth? }\end{array}$ & $\begin{array}{l}\text { Randall K. Filer, Jan Hanousek and Nauro } \\
\text { Campos }\end{array}$ & September 1999 \\
\hline $\begin{array}{l}\text { No. 266: Objectivity, Proximity and } \\
\text { Adaptability in Corporate Governance }\end{array}$ & Arnoud W.A Boot and Jonathan R. Macey & September 1999 \\
\hline $\begin{array}{l}\text { No. 265: When the Future is not What it Used } \\
\text { to Be: Lessons from the Western European } \\
\text { Experience to Forecasting Education and } \\
\text { Training in Transitional Economies }\end{array}$ & $\begin{array}{l}\text { Nauro F. Campos, Gerard Hughes, Stepan } \\
\text { Jurajda, and Daniel Munich }\end{array}$ & September 1999 \\
\hline $\begin{array}{l}\text { No. 264: The Institutional Foundation of } \\
\text { Foreign-Invested Enterprises (FIEs) in China }\end{array}$ & Yasheng Huang & September 1999 \\
\hline $\begin{array}{l}\text { No. 263: The Changing Corporate } \\
\text { Governance Paradigm: Implications for } \\
\text { Transition and Developing Countries }\end{array}$ & $\begin{array}{l}\text { Erik Berglof and Ernst-Ludwig von } \\
\text { Thadden }\end{array}$ & June 1999 \\
\hline No. 262: Law Enforcement and Transition & Gerard Roland and Thierry Verdier & May 1999 \\
\hline $\begin{array}{l}\text { No. 261: Soft Budget Constraints, Pecuniary } \\
\text { Externality, and the Dual Track System }\end{array}$ & Jiahua Che & June 2000 \\
\hline $\begin{array}{l}\text { No. 260: Missing Market in Labor Quality: } \\
\text { The Role of Quality Markets in Transition }\end{array}$ & Gary H. Jefferson & July 1999 \\
\hline $\begin{array}{l}\text { No. 259: Do Corporate Global Environmental } \\
\text { Standards in Emerging Markets Create or } \\
\text { Destroy Market Value }\end{array}$ & $\begin{array}{l}\text { Glen Dowell, Stuart Hart and Bernard } \\
\text { Yeung }\end{array}$ & June 1999 \\
\hline
\end{tabular}

\begin{tabular}{|l|l|l|}
\hline $\begin{array}{l}\text { No. 258: Public Training and Outflows from } \\
\text { Unemployment }\end{array}$ & Patrick A. Puhani & June 1999 \\
\hline $\begin{array}{l}\text { No. 257: Ownership Versus Environment: } \\
\text { Why are Public Sector Firms Inefficient? }\end{array}$ & Ann P. Bartel and Ann E. Harrison & June 1999 \\
\hline
\end{tabular}

Working Papers are available at:

www.wdi.bus.umich.edu 


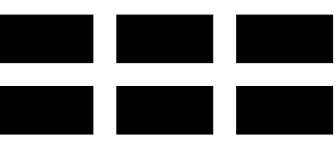

THE WILLIAM DAVIDSON INSTITUTE

AT THE UNIVERSITY OF MICHIGAN BUSINESSSCHOOL

\begin{tabular}{|c|c|c|}
\hline $\begin{array}{l}\text { No. 256: Taxation and Evasion in the } \\
\text { Presence of Exortion by Organized Crime }\end{array}$ & $\begin{array}{l}\text { Michael Alexeev, Eckhard Janeba and } \\
\text { Stefan Osborne }\end{array}$ & November 1999 \\
\hline $\begin{array}{l}\text { No. 255: Revisiting Hungary's Bankruptcy } \\
\text { Episode }\end{array}$ & John P. Bonin and Mark E. Schaffer & September 1999 \\
\hline $\begin{array}{l}\text { No. 254: FDI in Emerging Markets: A Home- } \\
\text { Country View }\end{array}$ & Marina v.N Whitman & June 1999 \\
\hline $\begin{array}{l}\text { No. 253: The Asian Financial Crisis: What } \\
\text { Happened, and What is to be Done }\end{array}$ & Jeffrey D. Sachs and Wing Thye Woo & January 1999 \\
\hline $\begin{array}{l}\text { No. 252: Organizational Law as Asset } \\
\text { Partitioning }\end{array}$ & Henry Hansmann and Reinier Kraakman & September 1999 \\
\hline $\begin{array}{l}\text { No. 251: Consumer Behavior Research in } \\
\text { Emerging Consumer Markets: the Case of the } \\
\text { Optimum Stimulation Level in South Africa }\end{array}$ & $\begin{array}{l}\text { Jan-Benedict E. M. Steenkamp and Steven } \\
\text { M. Burgess }\end{array}$ & September 1999 \\
\hline $\begin{array}{l}\text { No. 250: Property Rights Formation and the } \\
\text { Organization of Exchange and Production in } \\
\text { Rural China }\end{array}$ & $\begin{array}{l}\text { Matthew A. Turner, Loren Brandt, and } \\
\text { Scott Rozelle }\end{array}$ & July 1998 \\
\hline $\begin{array}{l}\text { No. 249: Impacts of the Indonesian Economic } \\
\text { Crisis: Price Changes and the Poor }\end{array}$ & $\begin{array}{l}\text { James Levinsohn, Steven Berry, and Jed } \\
\text { Friedman }\end{array}$ & June 1999 \\
\hline $\begin{array}{l}\text { No. 248: Internal Barriers in the Transition of } \\
\text { Enterprises from Central Plan to Market }\end{array}$ & Charalambos Vlachoutsicos & July 1999 \\
\hline $\begin{array}{l}\text { No. 247: Spillovers from Multinationals in } \\
\text { Developing Countries: the Mechanisms at } \\
\text { Work }\end{array}$ & Richard E. Caves & June 1999 \\
\hline $\begin{array}{l}\text { No. 246: Dynamism and Inertia on the } \\
\text { Russian Labour Market: } A \text { Model of } \\
\text { Segmentation }\end{array}$ & $\begin{array}{l}\text { Irena Grosfeld, Claudia Senik-Leygonie, } \\
\text { Thierry Verdier, Stanislav Kolenikov and } \\
\text { Elena Paltseva }\end{array}$ & May 1999 \\
\hline $\begin{array}{l}\text { No. 245: Lessons from Bank Privatization in } \\
\text { Central Europe }\end{array}$ & John Bonin and Paul Wachtel & May 1999 \\
\hline $\begin{array}{l}\text { No. 244: Nominal-Real Tradeoffs and the } \\
\text { Effects of Monetary Policy: the Romanian } \\
\text { Experience }\end{array}$ & Christian Popa & December 1998 \\
\hline $\begin{array}{l}\text { No. 243: Privatization, Political Risk and } \\
\text { Stock Market Development in Emerging } \\
\text { Economies }\end{array}$ & Enrico C. Perotti and Pieter van Oijen & March 1999 \\
\hline $\begin{array}{l}\text { No. 242: Investment Financing in Russian } \\
\text { Financial-Industrial Groups }\end{array}$ & Enrico C. Perotti and Stanislav Gelfer & October 1998 \\
\hline $\begin{array}{l}\text { No. 241: Can governments maintain hard } \\
\text { budget constraints? Bank lending and } \\
\text { financial isolation in Romania }\end{array}$ & $\begin{array}{l}\text { Octavian Carare, Constantijn Claessens, } \\
\text { Enrico C. Perotti }\end{array}$ & January 1999 \\
\hline $\begin{array}{l}\text { No. 240: Democratic Institutions and } \\
\text { Economic Reform: the Polish Case }\end{array}$ & $\begin{array}{l}\text { John E. Jackson, Jacek Klich, and } \\
\text { Krystyna Poznanska }\end{array}$ & April 1998 \\
\hline $\begin{array}{l}\text { No. 239: A Longitudinal Study of IJV } \\
\text { Performance in Eastern Europe }\end{array}$ & Keith D. Brouthers and Gary Bamossy & June 1999 \\
\hline $\begin{array}{l}\text { No. 238: Published in: Journal of Business } \\
\text { Venturing, "Firm Creation and Economic } \\
\text { Transitions" Vol. 14, Iss. 5,6 Sep/Nov 1999, } \\
\text { pp. 427-450. }\end{array}$ & $\begin{array}{l}\text { John E. Jackson, Jacek Klich, Krystyna } \\
\text { Poznanska }\end{array}$ & July 1998 \\
\hline $\begin{array}{l}\text { No. 237: Analysis of Entrepreneurial Attitudes } \\
\text { in Poland }\end{array}$ & $\begin{array}{l}\text { John E. Jackson and Aleksander S. } \\
\text { Marcinkowski }\end{array}$ & March 1997 \\
\hline $\begin{array}{l}\text { No. 236: Investment and Finance in De Novo } \\
\text { Private Firms: Empirical Results from the } \\
\text { Czech Republic, Hungary, and Poland }\end{array}$ & $\begin{array}{l}\text { Andrzej Bratkowski, Irena Grosfeld, Jacek } \\
\text { Rostowski }\end{array}$ & April 1999 \\
\hline
\end{tabular}

Working Papers are available at:

www.wdi.bus.umich.edu 


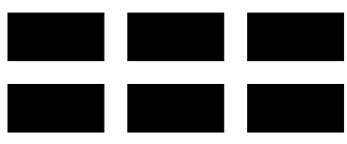

THE WILLIAM DAVIDSON INSTITUTE

AT THE UNIVERSITY OF MICHIGAN BUSINESSSCHOOL

\begin{tabular}{|c|c|c|}
\hline $\begin{array}{l}\text { No. 235: Does a Soft Macroeconomic } \\
\text { Environment Induce Restructuring on the } \\
\text { Microeconomic Level during the Transition } \\
\text { Period? Evidence from Investment Behavior } \\
\text { of Czech Enterprises }\end{array}$ & Lubomír Lizal & June 1999 \\
\hline $\begin{array}{l}\text { No. 234: Banking Reform in China: Gradually } \\
\text { Strengthening Pillar or Fragile Reed? }\end{array}$ & John Bonin & June 1999 \\
\hline $\begin{array}{l}\text { No. 233: Theories of Soft Budget Constraints } \\
\text { and the Analysis of Banking Crises }\end{array}$ & Janet Mitchell & March 1999 \\
\hline $\begin{array}{l}\text { No. 232: Unemployment Risk, Precautionary } \\
\text { Savings, and Moonlighting in Russia }\end{array}$ & $\begin{array}{l}\text { Alessandra Guariglia and Byung-Yeon } \\
\text { Kim }\end{array}$ & June 1999 \\
\hline $\begin{array}{l}\text { No. 231: Investing in Turbulent Times: The } \\
\text { Investment Behavior of Polish Firms in the } \\
\text { Transition }\end{array}$ & $\begin{array}{l}\text { Josef C. Brada, Arthur E. King, and Chia- } \\
\text { Ying Ma }\end{array}$ & April 1999 \\
\hline $\begin{array}{l}\text { No. 230: The End of Moderate Inflation in } \\
\text { Three Transition Economies? }\end{array}$ & Josef C. Brada and Ali M. Kutan & April 1999 \\
\hline $\begin{array}{l}\text { No. 229: Back to the Future: The Growth } \\
\text { Prospects of Transition Economies } \\
\text { Reconsidered }\end{array}$ & Nauro F. Campos & April 1999 \\
\hline $\begin{array}{l}\text { No. 228: The Enterprise Isolation Program in } \\
\text { Russia }\end{array}$ & Simeon Djankov & April 1999 \\
\hline $\begin{array}{l}\text { No. 227: Published in: Journal of } \\
\text { Comparative Economics, "Ownership } \\
\text { Concentration and Corporate Performance in } \\
\text { the Czech Republic" 27(3), September 1999, } \\
\text { pp. 498-513. }\end{array}$ & Stijn Claessens and Simeon Djankov & April 1999 \\
\hline $\begin{array}{l}\text { No. 226: Unemployment Benefit Entitlement } \\
\text { and Training Effects in Poland during } \\
\text { Transition }\end{array}$ & Patrick A. Puhani & March 1999 \\
\hline $\begin{array}{l}\text { No. 225: Transition at Whirlpool-Tatramat: } \\
\text { Case Studies }\end{array}$ & Hans Brechbuhl and Sonia Ferencikova & March 1999 \\
\hline $\begin{array}{l}\text { No. 224: Measuring Progress in Transition } \\
\text { and Towards EU Accession: A Comparison of } \\
\text { Manufacturing Firms in Poland, Romania, } \\
\text { and Spain }\end{array}$ & $\begin{array}{l}\text { Wendy Carlin, Saul Estrin, and Mark } \\
\text { Schaffer }\end{array}$ & March 1999 \\
\hline $\begin{array}{l}\text { No. 223: Product Market Competition in } \\
\text { Transition Economies: Increasing Varieties } \\
\text { and Consumer Loyalty }\end{array}$ & Mitsutoshi M. Adachi & March 1999 \\
\hline $\begin{array}{l}\text { No. 222: Opaque Markets and Rapid Growth: } \\
\text { the Superiority of Bank-Centered Financial } \\
\text { Systems for Developing Nations }\end{array}$ & Rodney Wallace & July 1999 \\
\hline $\begin{array}{l}\text { No. 221: Technology Spillovers through } \\
\text { Foreign Direct Investment }\end{array}$ & Yuko Kinoshita & January 1999 \\
\hline $\begin{array}{l}\text { No. 220: Managerial, Expertise and Team } \\
\text { Centered Forms of Organizing: A Cross- } \\
\text { Cultural Exploration of Independence in } \\
\text { Engineering Work }\end{array}$ & Leslie Perlow & January 1999 \\
\hline $\begin{array}{l}\text { No. 219: Household Structure and Labor } \\
\text { Demand in Agriculture: Testing for } \\
\text { Separability in Rural China }\end{array}$ & Audra J. Bowlus and Terry Sicular & January 1999 \\
\hline $\begin{array}{l}\text { No. 218: Competing Strategies of FDI and } \\
\text { Technology Transfer to China: American and }\end{array}$ & W. Mark Fruin and Penelope Prime & January 1999 \\
\hline
\end{tabular}

Working Papers are available at:

www.wdi.bus.umich.edu 


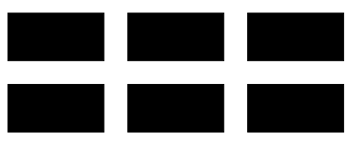

THE WILLIAM DAVIDSON INSTITUTE

AT THE UNIVERSITY OF MICHIGAN BUSINESSSCHOOL

\begin{tabular}{|c|c|c|}
\hline Japanese Firms & & \\
\hline $\begin{array}{l}\text { No. } 217 \text { Published in: Journal of } \\
\text { Comparative Economics, "Returns to } \\
\text { Mobility in the Transition to a Market } \\
\text { Economy" Vol. 27, No. 1, March 1999, pp. 4- }\end{array}$ & Tito Boeri and Christopher J. Flinn & January 1999 \\
\hline $\begin{array}{l}\text { No. } 216 \text { Published in: Journal of } \\
\text { Comparative Economics, "Labor Market } \\
\text { Policies and Unemployment in the Czech } \\
\text { Republic." Vol. 27, No. 1, March 1999, pp. } \\
\text { 33-60. }\end{array}$ & Katherine Terrell and Vit Sorm & November 1998 \\
\hline $\begin{array}{l}\text { No. } 215 \text { Published in: Journal of } \\
\text { Comparative Economics, “Active Labor } \\
\text { Market Policies in Poland: Human Capital } \\
\text { Enhancement, Stigmatization or Benefit } \\
\text { Churning?” Vol. 27, No. 1, March 1999, pp. } \\
\text { 61- }\end{array}$ & $\begin{array}{l}\text { Jochen Kluve, Hartmut Lehmann, and } \\
\text { Christoph M. Schmidt }\end{array}$ & December 1998 \\
\hline $\begin{array}{l}\text { No. } 214 \text { Published in: Journal of } \\
\text { Comparative Economics, “Does the Slovenian } \\
\text { Public Work Program Increase Participants' } \\
\text { Chances to Find a Job?” Vol. 27, No.1, } \\
\text { March 1999, pp. 113- }\end{array}$ & Milan Vodopivec & December 1998 \\
\hline $\begin{array}{l}\text { No. } 213 \text { Published in: Journal of } \\
\text { Comparative Economics, "Effects of Active } \\
\text { Labor Market Programs on the Transition } \\
\text { Rate from Unemployment into Regular Jobs in } \\
\text { the Slovak Republic." Vol. 27, No. 1, March } \\
\text { 1999, pp. 90- }\end{array}$ & Martina Lubyova and Jan C. van Ours & December 1998 \\
\hline $\begin{array}{l}\text { No. 212: The Marketing System in Bulgarian } \\
\text { Livestock Production - The Present State and } \\
\text { Evolutionary Processes During the Period of } \\
\text { Economic Transition }\end{array}$ & Yordan Staykov, Team Leader & October 1998 \\
\hline $\begin{array}{l}\text { No. 211: Bankruptcy Experience in Hungary } \\
\text { and the Czech Republic }\end{array}$ & Janet Mitchell & October 1998 \\
\hline $\begin{array}{l}\text { No 210: Values, Optimum Stimulation Levels } \\
\text { and Brand Loyalty: New Scales in New } \\
\text { Populations }\end{array}$ & Steven M. Burgess and Mari Harris & September 1998 \\
\hline $\begin{array}{l}\text { No. 209: Inherited Wealth, Corporate Control } \\
\text { and Economic Growth }\end{array}$ & $\begin{array}{l}\text { Randall K. Morck, David A. Stangeland, } \\
\text { and Bernard Yeung }\end{array}$ & September 1998 \\
\hline $\begin{array}{l}\text { No. 208: A Cultural Analysis of Homosocial } \\
\text { Reproduction and Contesting Claims to } \\
\text { Competence in Transitional Firms }\end{array}$ & Michael D. Kennedy & July 1998 \\
\hline $\begin{array}{l}\text { No. 207: From Survival to Success: The } \\
\text { Journey of Corporate Transformation at } \\
\text { Haier. Forthcoming in Teaching the } \\
\text { Dinosaurs to Dance: Organizational Change } \\
\text { in Transition Economies ed. Daniel Denison. }\end{array}$ & Arthur Yeung and Kenneth DeWoskin & July 1998 \\
\hline $\begin{array}{l}\text { No. 206: Why Do People Work If They Are } \\
\text { Not Paid? An Example from Eastern Europe. } \\
\text { Forthcoming in Teaching the Dinosaurs to } \\
\text { Dance: Organizational Change in Transition } \\
\text { Economies ed. Daniel Denison. }\end{array}$ & Irina L. Zinovieva & May 1998 \\
\hline No. 205: Firm Ownership and Work & Robert A. Roe, Irina L. Zinovieva, & May 1998 \\
\hline
\end{tabular}

Working Papers are available at:

www.wdi.bus.umich.edu 


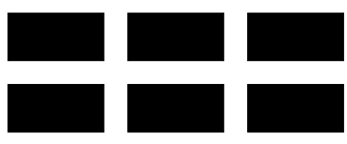

THE WILLIAM DAVIDSON INSTITUTE

AT THE UNIVERSITY OF MICHIGAN BUSINESSSCHOOL

\begin{tabular}{|c|c|c|}
\hline $\begin{array}{l}\text { Motivation in Bulgaria and Hungary: An } \\
\text { Empirical Study of the Transition in the Mid- } \\
\text { 1990s. Forthcoming in Teaching the } \\
\text { Dinosaurs to Dance: Organizational Change } \\
\text { in Transition Economies ed. Daniel Denison. }\end{array}$ & Elizabeth Dienes, and Laurens A. ten Horn & \\
\hline $\begin{array}{l}\text { No. 204: Human Resource Management in the } \\
\text { Restructuring of Chinese Joint Ventures. } \\
\text { Forthcoming in Teaching the Dinosaurs to } \\
\text { Dance: Organizational Change in Transition } \\
\text { Economies ed. Daniel Denison. }\end{array}$ & Nandani Lynton & April 1998 \\
\hline $\begin{array}{l}\text { No. 203: Emergent Compensation Strategies } \\
\text { in Post-Socialist Poland: Understanding the } \\
\text { Cognitive Underpinnings of Management } \\
\text { Practices in a Transition Economy. } \\
\text { Forthcoming in Teaching the Dinosaurs to } \\
\text { Dance: Organizational Change in Transition } \\
\text { Economies ed. Daniel Denison. }\end{array}$ & Marc Weinstein & March 1998 \\
\hline $\begin{array}{l}\text { No. 202: Corporate Transformation and } \\
\text { Organizational Learning: The People's } \\
\text { Republic of China. Forthcoming in Teaching } \\
\text { the Dinosaurs to Dance: Organizational } \\
\text { Change in Transition Economies ed. Daniel } \\
\text { Denison. }\end{array}$ & Meinolf Dierkes and Zhang Xinhua & March 1998 \\
\hline $\begin{array}{l}\text { No. 201: Foreign Direct Investment as a } \\
\text { Factor of Change: The Case of Slovakia. } \\
\text { Forthcoming in Teaching the Dinosaurs to } \\
\text { Dance: Organizational Change in Transition } \\
\text { Economies ed. Daniel Denison. }\end{array}$ & Sonia Ferencikova & February 1998 \\
\hline $\begin{array}{l}\text { No. 200: Radical versus Incremental Change: } \\
\text { The Role of Capabilities, Competition, and } \\
\text { Leaders. Forthcoming in Teaching the } \\
\text { Dinosaurs to Dance: Organizational Change } \\
\text { in Transition Economies ed. Daniel Denison. }\end{array}$ & Karen L. Newman & February 1998 \\
\hline $\begin{array}{l}\text { No. 199: The Emergence of Market Practices } \\
\text { in China's Economic Transition: Price Setting } \\
\text { Practices in Shanghai's Industrial Firms. } \\
\text { Forthcoming in Teaching the Dinosaurs to } \\
\text { Dance: Organizational Change in Transition } \\
\text { Economies ed. Daniel Denison. }\end{array}$ & Douglas Guthrie & February 1998 \\
\hline $\begin{array}{l}\text { No. 198: The Application of Change } \\
\text { Management Methods at Business } \\
\text { Organizations Operating in Hungary: } \\
\text { Challenges in the Business and Cultural } \\
\text { Environment and First Practical Experiences. } \\
\text { Forthcoming in Teaching the Dinosaurs to } \\
\text { Dance: Organizational Change in Transition } \\
\text { Economies ed. Daniel Denison. }\end{array}$ & Dr. János Fehér & January 1998 \\
\hline $\begin{array}{l}\text { No. 197: Organizational Changes in Russian } \\
\text { Industrial Enterprises: Mutation of Decision- } \\
\text { Making Structures and Transformations of } \\
\text { Ownership. Forthcoming in Teaching the } \\
\text { Dinosaurs to Dance: Organizational Change }\end{array}$ & Igor B. Gurkov & January 1998 \\
\hline
\end{tabular}

Working Papers are available at: www.wdi.bus.umich.edu 


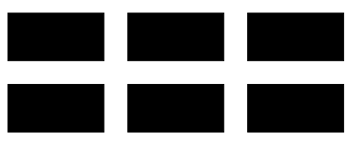

THE WILLIAM DAVIDSON INSTITUTE

AT THE UNIVERSITY OF MICHIGAN BUSINESSSCHOOL

\begin{tabular}{|c|c|c|}
\hline in Transition Economies ed. Daniel Denison. & & \\
\hline $\begin{array}{l}\text { No. 196: Understanding and Managing } \\
\text { Challenges to the Romanian Companies } \\
\text { during Transition. Forthcoming in Teaching } \\
\text { the Dinosaurs to Dance: Organizational } \\
\text { Change in Transition Economies ed. Daniel } \\
\text { Denison. }\end{array}$ & Dan Candea and Rodica M. Candea & January 1998 \\
\hline $\begin{array}{l}\text { No. 195: Insider Lending and Economic } \\
\text { Transition: The Structure, Function, and } \\
\text { Performance Impact of Finance Companies in } \\
\text { Chinese Business Groups. Forthcoming in } \\
\text { Teaching the Dinosaurs to Dance: } \\
\text { Organizational Change in Transition } \\
\text { Economies ed. Daniel Denison. }\end{array}$ & Lisa A. Keister & December 1997 \\
\hline $\begin{array}{l}\text { No. 194: Japanese Investment in Transitional } \\
\text { Economies: Characteristics and Performance. } \\
\text { Forthcoming in Teaching the Dinosaurs to } \\
\text { Dance: Organizational Change in Transition } \\
\text { Economies ed. Daniel Denison. }\end{array}$ & Paul W. Beamish and Andrew Delios & November 1997 \\
\hline $\begin{array}{l}\text { No. 193: Building Successful Companies in } \\
\text { Transition Economies. Forthcoming in } \\
\text { Teaching the Dinosaurs to Dance: } \\
\text { Organizational Change in Transition } \\
\text { Economies ed. Daniel Denison. }\end{array}$ & Dr. Ivan Perlaki & January 1998 \\
\hline $\begin{array}{l}\text { No. 192: Russian Communitariansim: An } \\
\text { Invisible Fist in the Transformation Process of } \\
\text { Russia. Forthcoming in Teaching the } \\
\text { Dinosaurs to Dance: Organizational Change } \\
\text { in Transition Economies ed. Daniel Denison. }\end{array}$ & Charalambos Vlachoutsicos & July 1998 \\
\hline No. 191: Teaching the Dinosaurs to Dance & Michal Cakrt & September 1997 \\
\hline $\begin{array}{l}\text { No. 190: Strategic Restructuring: Making } \\
\text { Capitalism in Post-Communist Eastern } \\
\text { Europe. Forthcoming in Teaching the } \\
\text { Dinosaurs to Dance: Organizational Change } \\
\text { in Transition Economies ed. Daniel Denison. }\end{array}$ & Lawrence P. King & September 1997 \\
\hline $\begin{array}{l}\text { No. 189: Published in: Regional Science and } \\
\text { Urban Economics, "Russia's Internal } \\
\text { Border", 29 (5), September 1999. }\end{array}$ & Daniel Berkowitz and David N. DeJong & July 1998 \\
\hline $\begin{array}{l}\text { No. 187: Corporate Structure and } \\
\text { Performance in Hungary }\end{array}$ & László Halpern and Gábor Kórsöi & July 1998 \\
\hline $\begin{array}{l}\text { No. 186: Performance of Czech Companies by } \\
\text { Ownership Structure }\end{array}$ & Andrew Weiss and Georgiy Nikitin & June 1998 \\
\hline $\begin{array}{l}\text { No. 185: Firm Performance in Bulgaria and } \\
\text { Estonia: The effects of competitive pressure, } \\
\text { financial pressure and disorganisation }\end{array}$ & Jozef Konings & July 1998 \\
\hline $\begin{array}{l}\text { No. 184: Investment and Wages during the } \\
\text { Transition: Evidence from Slovene Firms }\end{array}$ & Janez Prasnikar and Jan Svejnar & July 1998 \\
\hline $\begin{array}{l}\text { No. 183: Investment Portfolio under Soft } \\
\text { Budget: Implications for Growth, Volatility } \\
\text { and Savings }\end{array}$ & Chongen Bai and Yijiang Wang & July 1998 \\
\hline $\begin{array}{l}\text { No. 181: Delegation and Delay in Bank } \\
\text { Privatization }\end{array}$ & Loránd Ambrus-Lakatos and Ulrich Hege & July 1998 \\
\hline
\end{tabular}

Working Papers are available at:

www.wdi.bus.umich.edu 


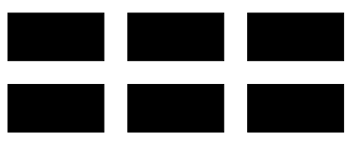

THE WILLIAM DAVIDSON INSTITUTE AT THE UNIVERSITY OF MICHIGAN BUSINESSSCHOOL

\begin{tabular}{|c|c|c|}
\hline $\begin{array}{l}\text { No. 180: Financing Mechanisms and } R \& D \\
\text { Investment }\end{array}$ & Haizhou Huang and Chenggang Xu & July 1998 \\
\hline $\begin{array}{l}\text { No. 179: Organizational Culture and } \\
\text { Effectiveness: The Case of Foreign Firms in } \\
\text { Russia }\end{array}$ & Carl F. Fey and Daniel R. Denison & January 1999 \\
\hline $\begin{array}{l}\text { No. 178: Output and Unemployment } \\
\text { Dynamics in Transition }\end{array}$ & Vivek H. Dehejia and Douglas W. Dwyer & January 1998 \\
\hline $\begin{array}{l}\text { No. 177: Published in: Economics of } \\
\text { Transition,, "Bureaucracies in the Russian } \\
\text { Voucher Privatization" Vol. 8, No. 1, 2000, } \\
\text { pp. 37-57. }\end{array}$ & Guido Friebel & June 1998 \\
\hline $\begin{array}{l}\text { No. 176: Chronic Moderate Inflation in } \\
\text { Transition: The Tale of Hungary }\end{array}$ & János Vincze & June 1998 \\
\hline $\begin{array}{l}\text { No. 175: Privatisation and Market Structure } \\
\text { in a Transition Economy }\end{array}$ & John Bennett and James Maw & June 1998 \\
\hline $\begin{array}{l}\text { No. 174: Ownership and Managerial } \\
\text { Competition: Employee, Customer, or Outside } \\
\text { Ownership }\end{array}$ & Patrick Bolton and Chenggang Xu & June 1998 \\
\hline $\begin{array}{l}\text { No. 173: Intragovernment Procurement of } \\
\text { Local Public Good: A Theory of } \\
\text { Decentralization in Nondemocratic } \\
\text { Government }\end{array}$ & Chong-en Bai, Yu Pan and Yijiang Wang & June 1998 \\
\hline $\begin{array}{l}\text { No. 172: Political Instability and Growth in } \\
\text { Proprietary Economies }\end{array}$ & Jody Overland and Michael Spagat & August 1998 \\
\hline $\begin{array}{l}\text { No. 171: Published in Post-Communist } \\
\text { Economies, "Framework Issues in the } \\
\text { Privatization Strategies of the Czech Republic, } \\
\text { Hungary, and Poland" Vol. 11, no. 1 March } \\
\text { 1999. }\end{array}$ & Morris Bornstein & June 1998 \\
\hline $\begin{array}{l}\text { No. 170: Published in: European Journal of } \\
\text { Political Economy "Privatization, Ownership } \\
\text { Structure and Transparency: How to Measure } \\
\text { a Real Involvement of the State" 15(4), } \\
\text { November 1999, pp. 605-18. }\end{array}$ & Frantisek Turnovec & May 1998 \\
\hline $\begin{array}{l}\text { No. } 169 \text { Published in: American Economic } \\
\text { Review, "Unemployment and the Social Safety } \\
\text { Net during Transitions to a Market Economy: } \\
\text { Evidence from Czech and Slovak Men." Vol. } \\
\text { 88, No. 5, Dec. 1998, pp. 1117-1142. }\end{array}$ & $\begin{array}{l}\text { John C. Ham, Jan Svejnar, and Katherine } \\
\text { Terrell }\end{array}$ & December 1998 \\
\hline $\begin{array}{l}\text { No. 167: Voucher Privatization with } \\
\text { Investment Funds: An Institutional Analysis }\end{array}$ & David Ellerman & March 1998 \\
\hline $\begin{array}{l}\text { No. 166: Published in: Marketing Issues in } \\
\text { Transitional Economies, "Value Priorities } \\
\text { and Consumer Behavior in a Transitional } \\
\text { Economy: The Case of South Africa” ed. } \\
\text { Rajeev Batra. }\end{array}$ & $\begin{array}{l}\text { Steven M. Burgess and Jan-Benedict E.M. } \\
\text { Steenkamp }\end{array}$ & August 1998 \\
\hline $\begin{array}{l}\text { No. 164: Finance and Investment in } \\
\text { Transition: Czech Enterprises, 1993-1994 }\end{array}$ & Ronald Anderson and Chantal Kegels & September 1997 \\
\hline $\begin{array}{l}\text { No. 163: European Union Trade and } \\
\text { Investment Flows U-Shaping Industrial } \\
\text { Output in Central and Eastern Europe: } \\
\text { Theory and Evidence }\end{array}$ & Alexander Repkine and Patrick P. Walsh & April 1998 \\
\hline
\end{tabular}

Working Papers are available at: www.wdi.bus.umich.edu 


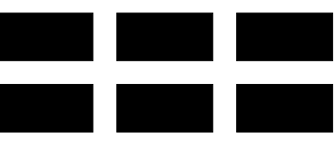

THE WILLIAM DAVIDSON INSTITUTE

AT THE UNIVERSITY OF MICHIGAN BUSINESSSCHOOL

\begin{tabular}{|c|c|c|}
\hline $\begin{array}{l}\text { No. 162: Skill Acquisition and Private Firm } \\
\text { Creation in Transition Economies }\end{array}$ & Zuzana Brixiova and Wenli Li & October 1999 \\
\hline No. 161: Corruption in Transition & Susanto Basu and David D. Li & May 1998 \\
\hline $\begin{array}{l}\text { No. 160a: Tenures that Shook the World: } \\
\text { Worker Turnover in Russia, Poland and } \\
\text { Britain }\end{array}$ & $\begin{array}{l}\text { Hartmut Lehmann and Jonathan } \\
\text { Wadsworth }\end{array}$ & November 1999 \\
\hline $\begin{array}{l}\text { No. 160: Tenures that Shook the World: } \\
\text { Worker Turnover in the Russian Federation } \\
\text { and Poland }\end{array}$ & $\begin{array}{l}\text { Hartmut Lehmann and Jonathan } \\
\text { Wadsworth }\end{array}$ & June 1998 \\
\hline $\begin{array}{l}\text { No. 159: Does Market Structure Matter? New } \\
\text { Evidence from Russia }\end{array}$ & Annette N. Brown and J. David Brown & June 1998 \\
\hline $\begin{array}{l}\text { No. 158: Structural Adjustment and Regional } \\
\text { Long Term Unemployment in Poland }\end{array}$ & Hartmut Lehmann and Patrick P. Walsh & June 1997 \\
\hline $\begin{array}{l}\text { No. 157: Baby Boom or Bust? Changing } \\
\text { Fertility in Post-Communist Czech Republic } \\
\text { and Slovakia }\end{array}$ & Robert S. Chase & April 1998 \\
\hline $\begin{array}{l}\text { No. } 156 \text { Published in: Leadership and } \\
\text { Organization Development Journal, } \\
\text { "Leading Radical Change in Transition } \\
\text { Economies." Vol. 19, No. 6, 1998, pp. 309- } \\
324 .\end{array}$ & Karen L. Newman & June 1998 \\
\hline $\begin{array}{l}\text { No. } 155 \text { Published in: Oxford Review of } \\
\text { Economic Policy, "From Theory into } \\
\text { Practice? Restructuring and Dynamism in } \\
\text { Transition Economies." Vol. 13, No. 2, } \\
\text { Summer 1997, pp. 77-105. } \\
\end{array}$ & Wendy Carlin and Michael Landesmann & June 1997 \\
\hline $\begin{array}{l}\text { No. 154: The Model and the Reality: } \\
\text { Assessment of Vietnamese SOE Reform- } \\
\text { Implementation at the Firm Level }\end{array}$ & $\begin{array}{l}\text { Edmund Malesky, Vu Thanh Hung, Vu Thi } \\
\text { Dieu Anh, and Nancy K. Napier }\end{array}$ & July 1998 \\
\hline $\begin{array}{l}\text { No. } 153 \text { Published in: Journal of } \\
\text { Comparative Economics, "Causes of the Soft } \\
\text { Budget Constraint: Evidence on Three } \\
\text { Explanations." Vol. 26, No. 1, March 1998, } \\
\text { pp. 104-116. }\end{array}$ & David D. Li and Minsong Liang & March 1998 \\
\hline $\begin{array}{l}\text { No. } 152 \text { Published in: Comparative Economic } \\
\text { Studies, "Enterprise Restructuring in Russia's } \\
\text { Transition Economy: Formal and Informal } \\
\text { Mechanisms." Vol. 40, No. 2, Summer 1998, } \\
\text { pp. 5-52. }\end{array}$ & Susan J. Linz and Gary Krueger & April 1998 \\
\hline $\begin{array}{l}\text { No. 151: Labor Productivity in Transition: A } \\
\text { Regional Analysis of Russian Industry }\end{array}$ & Susan J. Linz & May 1998 \\
\hline $\begin{array}{l}\text { No. 150: Tax Avoidance and the Allocation of } \\
\text { Credit. Forthcoming in Financial Systems in } \\
\text { Transition: The Design of Financial Systems } \\
\text { in Central Europe eds. Anna Meyendorff and } \\
\text { Anjan Thakor. }\end{array}$ & Anna Meyendorff & June 1998 \\
\hline $\begin{array}{l}\text { No. 149: Commitment, Versatility and } \\
\text { Balance: Determinants of Work Time } \\
\text { Standards and Norms in a Multi-Country } \\
\text { Study of Software Engineers }\end{array}$ & Leslie Perlow and Ron Fortgang & April 1998 \\
\hline $\begin{array}{l}\text { No. 148: Changes in Poland's Transfer } \\
\text { Payments in the 1990s: the Fate of }\end{array}$ & Bozena Leven & June 1998 \\
\hline
\end{tabular}

Working Papers are available at:

www.wdi.bus.umich.edu 


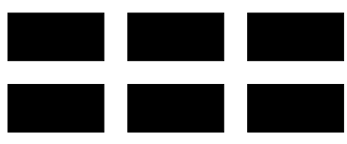

THE WILLIAM DAVIDSON INSTITUTE

AT THE UNIVERSITY OF MICHIGAN BUSINESSSCHOOL

\begin{tabular}{|c|c|c|}
\hline Pensioners & & \\
\hline $\begin{array}{l}\text { No. 147: Environmental Protection and } \\
\text { Economic Development: The Case of the } \\
\text { Huaihe River Basin Cleanup Plan }\end{array}$ & $\begin{array}{l}\text { Robert Letovsky, Reze Ramazani, and } \\
\text { Debra Murphy }\end{array}$ & June 1998 \\
\hline $\begin{array}{l}\text { No. 146: Chief Executive Compensation } \\
\text { During Early Transition: Further Evidence } \\
\text { from Bulgaria }\end{array}$ & $\begin{array}{l}\text { Derek C. Jones, Takao Kato, and Jeffrey } \\
\text { Miller }\end{array}$ & June 1998 \\
\hline $\begin{array}{l}\text { No. } 145 \text { Published in: Economics of } \\
\text { Transition, "Women's Unemployment During } \\
\text { the Transition: Evidence from Czech and } \\
\text { Slovak Micro Data," Vol. 7, No. 1, May 1999, } \\
\text { pp. 47-78. }\end{array}$ & $\begin{array}{l}\text { John Ham, Jan Svejnar, and Katherine } \\
\text { Terrell }\end{array}$ & May 1998 \\
\hline No. 144: Investment and Wages in Slovenia & Janez Prasnikar & May 1998 \\
\hline $\begin{array}{l}\text { No. } 143 \text { Published in: Review of Financial } \\
\text { Studies, “Optimal Bankruptcy Laws Across } \\
\text { Different Economic Systems," 12(2), Summer } \\
\text { 1999, pgs. 347-77. }\end{array}$ & Elazar Berkovitch and Ronen Israel & March 1998 \\
\hline $\begin{array}{l}\text { No. 142: Industrial Policy and Poverty in } \\
\text { Transition Economies: Two Steps Forward or } \\
\text { One Step Back? }\end{array}$ & Susan J. Linz & March 1998 \\
\hline $\begin{array}{l}\text { No. 141: Collective Ownership and } \\
\text { Privatization of China's Village Enterprises }\end{array}$ & Suwen Pan and Albert Park & April 1998 \\
\hline $\begin{array}{l}\text { No. 140: A Comparative Look at Labor } \\
\text { Mobility in the Czech Republic: Where have } \\
\text { all the Workers Gone? }\end{array}$ & Vit Sorm and Katherine Terrell & April 1999 \\
\hline $\begin{array}{l}\text { No. 139: The Failure of the Government-Led } \\
\text { Program of Corporate Reorganization in } \\
\text { Romania }\end{array}$ & Simeon Djankov and Kosali Ilayperuma & September 1997 \\
\hline $\begin{array}{l}\text { No. 138: Ownership and Employment in } \\
\text { Russian Industry: 1992-1995 }\end{array}$ & Susan J. Linz & March 1998 \\
\hline $\begin{array}{l}\text { No. } 137 \text { Published in: Journal of Political } \\
\text { Economy, “Reform Without Losers: An } \\
\text { Interpretation of China's Dual-Track } \\
\text { Approach to Transition," Feb. 2000; Vol. 108, } \\
\text { Iss. 1; pg. } 120\end{array}$ & $\begin{array}{l}\text { Lawrence J. Lau, Yingyi Qian, and Gerard } \\
\text { Roland }\end{array}$ & November 1997 \\
\hline $\begin{array}{l}\text { No. } 136 \text { Published in: European Economic } \\
\text { Review, "The Political Economy of Mass } \\
\text { Privatization and the Risk of Expropriation," } \\
\text { 44(2), February 2000, pgs. 393-421 }\end{array}$ & Klaus M. Schmidt & March 1998 \\
\hline $\begin{array}{l}\text { No. 135: Radical Organizational Change: The } \\
\text { Role of Starting Conditions, Competition, and } \\
\text { Leaders }\end{array}$ & Karen L. Newman & January 1998 \\
\hline $\begin{array}{l}\text { No. 134: To Restructure or Not to } \\
\text { Restructure: Informal Activities and } \\
\text { Enterprise Behavior in Transition }\end{array}$ & Clifford Gaddy and Barry W. Ickes & May 1998 \\
\hline $\begin{array}{l}\text { No. 133: Management 101: Behavior of Firms } \\
\text { in Transition Economies }\end{array}$ & Josef C. Brada & March 1998 \\
\hline $\begin{array}{l}\text { No. } 132 \text { Published in: Quarterly Journal of } \\
\text { Economics, "Interfirm Relationships and } \\
\text { Informal Credit in Vietnam," 114(4), Nov. } \\
\text { 1999, pgs. 1285-1320 }\end{array}$ & John McMillan and Christopher Woodruff & February 1998 \\
\hline No. 131 Published in: Comparative Economic & John B. Bonin and Istvan Abel & March 1998 \\
\hline
\end{tabular}

Working Papers are available at:

www.wdi.bus.umich.edu 


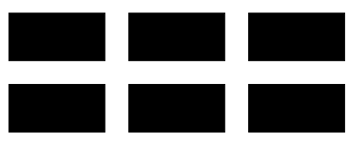

THE WILLIAM DAVIDSON INSTITUTE

AT THE UNIVERSITY OF MICHIGAN BUSINESSSCHOOL

\begin{tabular}{|c|c|c|}
\hline $\begin{array}{l}\text { Studies, “Will Restructuring Hungarian } \\
\text { Companies Innovate? An Investigation Based } \\
\text { on Joseph Berliner's Analysis of Innovation in } \\
\text { Soviet Industry.”Vol. 40, No. 2, Summer } \\
\text { 1998, pp. 53-74. }\end{array}$ & & \\
\hline $\begin{array}{l}\text { No. 130: Published in The American } \\
\text { Economic Review, “Changing Incentives of } \\
\text { the Chinese Bureaucracy.” May, } 1998 .\end{array}$ & David D. $L i$ & January 1998 \\
\hline $\begin{array}{l}\text { No. 129: Restructuring Investment in } \\
\text { Transition: A Model of the Enterprise } \\
\text { Decision }\end{array}$ & Richard E. Ericson & January 1998 \\
\hline $\begin{array}{l}\text { No. } 128 \text { Published in: Comparative Economic } \\
\text { Studies, “Job Rights in Russian Firms: } \\
\text { Endangered or Extinct Institutions?” Vol. 40, } \\
\text { No. 4, Winter 1998, pp. 1-32. }\end{array}$ & Susan J. Linz & January 1998 \\
\hline $\begin{array}{l}\text { No. 127: Accounting for Growth in Post- } \\
\text { Soviet Russia }\end{array}$ & Daniel Berkowitz and David N. DeJong & January 1998 \\
\hline $\begin{array}{l}\text { No. } 126 \text { Published in: Economics of } \\
\text { Transition, "From Federalism, Chinese Style, } \\
\text { to Privatization Chinese Style," 7(1), 1999, } \\
\text { pgs. } 103-31\end{array}$ & $\begin{array}{l}\text { Yuanzheng Cao, Yingyi Qian, and Barry R. } \\
\text { Weingast }\end{array}$ & December 1997 \\
\hline $\begin{array}{l}\text { No. 125: Market Discipline in Conglomerate } \\
\text { Banks: Is an Internal Allocation of Cost of } \\
\text { Capital Necessary as Incentive Device? } \\
\text { Forthcoming in Financial Systems in } \\
\text { Transition: The Design of Financial Systems } \\
\text { in Central Europe eds. Anna Meyendorff and } \\
\text { Anjan Thakor. }\end{array}$ & Arnoud W. A. Boot and Anjolein Schmeits & November 1997 \\
\hline $\begin{array}{l}\text { No. 124: Financial Discipline in the } \\
\text { Enterprise Sector in Transition Countries: } \\
\text { How Does China Compare? }\end{array}$ & Shumei Gao and Mark E. Schaffer & February 1998 \\
\hline $\begin{array}{l}\text { No. 123: Considerations of an Emerging } \\
\text { Marketplace: Managers' Perceptions in the } \\
\text { Southern African Economic Community }\end{array}$ & Brent Chrite and David Hudson & February 1998 \\
\hline $\begin{array}{l}\text { No. 122: A Model of the Informal Economy in } \\
\text { Transition Economies }\end{array}$ & $\begin{array}{l}\text { Simon Commander and Andrei } \\
\text { Tolstopiatenko }\end{array}$ & November 1997 \\
\hline $\begin{array}{l}\text { No. 121: Local Labour Market Dynamics in } \\
\text { the Czech and Slovak Republics }\end{array}$ & Peter Huber and Andreas Worgotter & November 1997 \\
\hline $\begin{array}{l}\text { No. 121: Local Labour Market Dynamics in } \\
\text { the Czech and Slovak Republics }\end{array}$ & Peter Huber and Andreas Worgotter & November 1997 \\
\hline $\begin{array}{l}\text { No. 119: Institutional Upheaval and Company } \\
\text { Transformation in Emerging Market } \\
\text { Economies }\end{array}$ & Karen L. Newman & March 1998 \\
\hline $\begin{array}{l}\text { No. 118: Industrial Decline and Labor } \\
\text { Reallocation in Romania }\end{array}$ & John S. Earle & October 1997 \\
\hline $\begin{array}{l}\text { No. 117: Notes for an Essay on the Soft } \\
\text { Budget Constraint }\end{array}$ & Lorand Ambrus-Lakatos & January 1997 \\
\hline $\begin{array}{l}\text { No. 116: Labor Demand During Transition in } \\
\text { Hungary }\end{array}$ & Gabor Korosi & October 1997 \\
\hline $\begin{array}{l}\text { No. 115: Enterprise Performance and } \\
\text { Managers' Profiles }\end{array}$ & Simeon Djankov and Stijn Claessens & December 1997 \\
\hline No. $114 \mathrm{~b}$ Employment and Wages in & Swati Basu, Saul Estrin, and Jan Svejnar & April 2000 \\
\hline
\end{tabular}

Working Papers are available at:

www.wdi.bus.umich.edu 


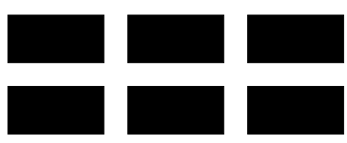

THE WILLIAM DAVIDSON INSTITUTE

AT THE UNIVERSITY OF MICHIGAN BUSINESSSCHOOL

\begin{tabular}{|c|c|c|}
\hline $\begin{array}{l}\text { Enterprises under Communism and in } \\
\text { Transition: Evidence From Central Europe } \\
\text { and Russia }\end{array}$ & & \\
\hline $\begin{array}{l}\text { No. 114: Employment and Wage Behavior of } \\
\text { Enterprises in Transitional Economies }\end{array}$ & Swati Basu, Saul Estrin, and Jan Svejnar & October 1997 \\
\hline $\begin{array}{l}\text { No. 113: Preliminary Evidence on Active } \\
\text { Labor Programs' Impact in Hungary and } \\
\text { Poland }\end{array}$ & Christopher J. O’Leary & October 1997 \\
\hline $\begin{array}{l}\text { No. 111: Unemployment Benefits and } \\
\text { Incentives in Hungary: New Evidence }\end{array}$ & Joachim Wolff & October 1997 \\
\hline $\begin{array}{l}\text { No. 110: Published in: Empirical Economics, } \\
\text { "Long-Term Unemployment, Unemployment } \\
\text { Benefits and Social Assistance: The Polish } \\
\text { Experience" Empirical-Economics; 23(1-2), } \\
\text { 1998, pages 55-85. }\end{array}$ & Marek Gora and Christoph M. Schmidt & April 1997 \\
\hline $\begin{array}{l}\text { No. } 109 \text { Published in: Industrial and Labor } \\
\text { Relations Review, "Markets for Communist } \\
\text { Human Capital: Returns to Education and } \\
\text { Experience in Post-Communist Czech } \\
\text { Republic and Slovakia." Vol. 51, No. 3, April } \\
\text { 1998, pp. 401-423. }\end{array}$ & Robert S. Chase & October 1997 \\
\hline $\begin{array}{l}\text { No. 107: The Worker-Firm Matching in the } \\
\text { Transition: (Why) Are the Czechs More } \\
\text { Successful Than Others? }\end{array}$ & $\begin{array}{l}\text { Daniel Münich, Jan Svejnar, and } \\
\text { Katherine Terrell }\end{array}$ & October 1997 \\
\hline $\begin{array}{l}\text { No. } 106 \text { Published in: Journal of } \\
\text { Comparative Economics, "Job Creation, Job } \\
\text { Destruction and Growth of Newly Established, } \\
\text { Privatized and State-Owned Enterprises in } \\
\text { Transition Economies: Survey Evidence from } \\
\text { Bulgaria, Hungary, and Romania," Vol. 26, } \\
\text { No.3, September 1998, pp. 429-445. }\end{array}$ & Valentijn Bilsen and Jozef Konings & September 1998 \\
\hline $\begin{array}{l}\text { No. 105: Getting Behind the East-West } \\
\text { [German] Wage Differential: Theory and } \\
\text { Evidence }\end{array}$ & Michael Burda and Christoph Schmidt & May 1997 \\
\hline $\begin{array}{l}\text { No. 104: The Birth of the "Wage Curve" in } \\
\text { Hungary, 1989-95 }\end{array}$ & Gabor Kertesi and Janos Kollo & October 1997 \\
\hline $\begin{array}{l}\text { No. 103: Published in: Journal of } \\
\text { Comparative Economics, "Grime and } \\
\text { Punishment: Job Insecurity and Wage Arrears } \\
\text { in the Russian Federation" 27, 595-617 } \\
\text { (1999). }\end{array}$ & $\begin{array}{l}\text { Hartmut Lehmann, Jonathan Wadsworth, } \\
\text { and Alessandro Acquisti }\end{array}$ & October 1997 \\
\hline No. 102: Social Networks in Transition & $\begin{array}{l}\text { Lorena Barberia, Simon Johnson, and } \\
\text { Daniel Kaufmann }\end{array}$ & October 1997 \\
\hline $\begin{array}{l}\text { No. 101: Depreciation and Russian Corporate } \\
\text { Finance: A Pragmatic Approach to Surviving } \\
\text { the Transition }\end{array}$ & Susan J. Linz & November 1997 \\
\hline No. 100: Romanian Financial System Reform & Anna Meyendorff and Anjan V. Thakor & November 1997 \\
\hline $\begin{array}{l}\text { No. 99: Proceedings of the Conference on } \\
\text { Strategic Alliances in Transitional Economies, } \\
\text { held May 20, } 1997 \text { at the Davidson Institute }\end{array}$ & Edited by Cynthia Koch & May 1997 \\
\hline $\begin{array}{l}\text { No. 98: Institutions, Strain and the } \\
\text { Underground Economy }\end{array}$ & Daniel Daianu and Lucian Albu & November 1997 \\
\hline
\end{tabular}

Working Papers are available at:

www.wdi.bus.umich.edu 


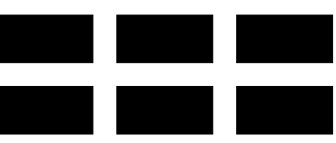

THE WILLIAM DAVIDSON INSTITUTE

AT THE UNIVERSITY OF MICHIGAN BUSINESSSCHOOL

\begin{tabular}{|c|c|c|}
\hline $\begin{array}{l}\text { No. 97: Structure and Strain in Explaining } \\
\text { Inter-Enterprise Arrears }\end{array}$ & Daniel Daianu & November 1997 \\
\hline $\begin{array}{l}\text { No. 96: Resource Misallocation and Strain: } \\
\text { Explaining Shocks in Post-Command } \\
\text { Economies }\end{array}$ & Daniel Daianu & November 1997 \\
\hline $\begin{array}{l}\text { No. 95: Published in: Finance-a-Uver, } \\
\text { "Czech Money Market: Emerging Links } \\
\text { Among Interest Rates." 48(2) } 1998 \text { pp. 99- } \\
\text { 109. }\end{array}$ & Jan Hanousek and Evzen Kocenda & November 1997 \\
\hline $\begin{array}{l}\text { No. 94: Pre-Reform Industry and the } \\
\text { State Monopsony in China }\end{array}$ & Xiao-Yuan Dong and Louis Putterman & October 1997 \\
\hline $\begin{array}{l}\text { No. 93: China's State-Owned Enterprises } \\
\text { In the First Reform Decade: } \\
\text { An Analysis of a Declining Monopsony }\end{array}$ & Xiao-Yuan Dong and Louis Putterman & October 1997 \\
\hline $\begin{array}{l}\text { No. 92: Expatriate Management in the Czech } \\
\text { Republic }\end{array}$ & Richard B. Peterson & September 1997 \\
\hline $\begin{array}{l}\text { No. 91: China and the Idea of Economic } \\
\text { Reform }\end{array}$ & Thomas G. Rawski & April 1997 \\
\hline $\begin{array}{l}\text { No. } 90 \text { Published in: China Economic } \\
\text { Review, "China's State Enterprise Reform: An } \\
\text { Overseas Perspective." Vol. 8, Spring 1997, } \\
\text { pp. 89-98. }\end{array}$ & Thomas G. Rawski & July 1997 \\
\hline $\begin{array}{l}\text { No. 89: The Economic Determinants of } \\
\text { Internal Migration Flows in Russia During } \\
\text { Transition }\end{array}$ & Annette N. Brown & July 1997 \\
\hline $\begin{array}{l}\text { No. 88: Gender Wage Gaps in China's Labor } \\
\text { Market: Size, Structure, Trends }\end{array}$ & $\begin{array}{l}\text { Margaret Maurer-Fazio, Thomas G. } \\
\text { Rawski, and Wei Zhang }\end{array}$ & July 1997 \\
\hline $\begin{array}{l}\text { No. 87: Privatisation in Central and Eastern } \\
\text { Europe }\end{array}$ & Saul Estrin & June 1997 \\
\hline $\begin{array}{l}\text { No. 86: Published in : Economics of } \\
\text { Transition, "The Effect of Privatization on } \\
\text { Wealth Distribution in Russia." v. 7, no. 2, } \\
\text { 1999, pp. 449-65 }\end{array}$ & Michael Alexeev & February 1998 \\
\hline $\begin{array}{l}\text { No. 85: Was Privatization in Eastern Germany } \\
\text { a Special Case? Some Lessons from the } \\
\text { Treuhand }\end{array}$ & Uwe Siegmund & September 1997 \\
\hline No. 84: Start-ups and Transition & Daniel M. Berkowitz and David J. Cooper & September 1997 \\
\hline $\begin{array}{l}\text { No. 83: Which Enterprises (Believe They) } \\
\text { Have Soft Budgets after Mass Privatization? } \\
\text { Evidence from Mongolia }\end{array}$ & $\begin{array}{l}\text { James Anderson, Georges Korsun, and } \\
\text { Peter Murrell }\end{array}$ & October 1997 \\
\hline $\begin{array}{l}\text { No. 82: Published in: European Economic } \\
\text { Review, "Unemployment Dynamics and the } \\
\text { Restructuring of the Slovak Unemployment } \\
\text { Benefit System." April, 1997. }\end{array}$ & Martina Lubyova and Jan C. van Ours & June 1997 \\
\hline $\begin{array}{l}\text { No. 81: Determinants of Unemployment } \\
\text { Duration in Russia }\end{array}$ & Mark C. Foley & August 1997 \\
\hline $\begin{array}{l}\text { No. 80: The Many Faces of Information } \\
\text { Disclosure }\end{array}$ & Arnoud W.A. Boot and Anjan V. Thakor & October 1997 \\
\hline $\begin{array}{l}\text { No. 79: Published in: Journal of Finance, } \\
\text { "Foreign Speculators and Emerging Equity } \\
\text { Markets."v.22, iss. 2, 2000, pp. 565-613 }\end{array}$ & Geert Bekaert and Campbell R. Harvey & August 1997 \\
\hline No. 78: The Relationship Between Economic & Jan Hanousek and Randall K. Filer & June 1997 \\
\hline
\end{tabular}

Working Papers are available at:

www.wdi.bus.umich.edu 


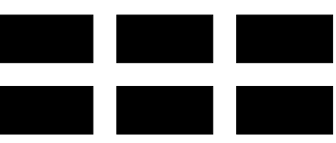

THE WILLIAM DAVIDSON INSTITUTE

AT THE UNIVERSITY OF MICHIGAN BUSINESSSCHOOL

\begin{tabular}{|c|c|c|}
\hline Factors and Equity Markets in Central Europe & & \\
\hline $\begin{array}{l}\text { No. } 77 \text { Published in: Economics of } \\
\text { Transition, "A Gini Decomposition Analysis } \\
\text { of Inequality in the Czech and Slovak } \\
\text { Republics During the Transition," Vol. 6, } \\
\text { No.1, May 1998, pp. 23-46. }\end{array}$ & Thesia I. Garner and Katherine Terrell & May 1998 \\
\hline $\begin{array}{l}\text { No. 76: China's Emerging Market for } \\
\text { Property Rights: Theoretical and Empirical } \\
\text { Perspectives }\end{array}$ & Gary H. Jefferson and Thomas G. Rawski & June 1997 \\
\hline $\begin{array}{l}\text { No. 75b: Test of Permanent Income } \\
\text { Hypothesis on Czech Voucher Privatization }\end{array}$ & Jan Hanousek and Zdenek Tima & October 1997 \\
\hline $\begin{array}{l}\text { No. 74: Determinants of Performance of } \\
\text { Manufacturing Firms in Seven European } \\
\text { Transition Economies }\end{array}$ & $\begin{array}{l}\text { Stijn Claessens, Simeon Djankov, and } \\
\text { Gerhard Pohl }\end{array}$ & February 1997 \\
\hline $\begin{array}{l}\text { No. } 73 \text { Published in: Economics of } \\
\text { Transition, "The Restructuring of Large } \\
\text { Firms in Slovak Republic." Vol. 6, No. 1, May } \\
\text { 1998, pp. 67-85 }\end{array}$ & Simeon Djankov and Gerhard Pohl & May 1998 \\
\hline $\begin{array}{l}\text { No. 72: Law, Relationships, and Private } \\
\text { Enforcement: Transactional Strategies of } \\
\text { Russian Enterprises }\end{array}$ & $\begin{array}{l}\text { Kathryn Hendley, Peter Murrell, and } \\
\text { Randi Ryterman }\end{array}$ & November 1998 \\
\hline $\begin{array}{l}\text { No. 71: Giving Credit Where Credit Is Due: } \\
\text { The Changing Role of Rural Financial } \\
\text { Institutions in China }\end{array}$ & Albert Park, Loren Brandt, and John Giles & March 1997 \\
\hline $\begin{array}{l}\text { No. 70: Privatization Versus Competition: } \\
\text { Changing Enterprise Behavior in Russia }\end{array}$ & John S. Earle and Saul Estrin & Spring 1997 \\
\hline $\begin{array}{l}\text { No. 69: Russian Managers under Storm: } \\
\text { Explicit Reality and Implicit Leadership } \\
\text { Theories (A Pilot Exploration) }\end{array}$ & Igor Gurkov & October 1998 \\
\hline $\begin{array}{l}\text { No. 68: The Political Economy of Central- } \\
\text { Local Relations in China: Inflation and } \\
\text { Investment Controls During the Reform Era }\end{array}$ & Yasheng Huang & Spring 1997 \\
\hline $\begin{array}{l}\text { No. 67: Between Two Coordination Failures: } \\
\text { Automotive Industrial Policy in China with a } \\
\text { Comparison to Korea }\end{array}$ & Yasheng Huang & Spring 1997 \\
\hline $\begin{array}{l}\text { No. } 66 \text { Published in: Post-Soviet Geography } \\
\text { and Economics, "Red Executives in Russia's } \\
\text { Transition Economy." Vol. 27, No. 10, } \\
\text { November 1996, pp. 633-651. }\end{array}$ & Susan J. Linz & January 1997 \\
\hline $\begin{array}{l}\text { No. } 65 \text { Published in: Industrial and } \\
\text { Corporate Change, "On the Sequencing of } \\
\text { Privatization in Transition Economies. "Vol. } \\
\text { 7, No. 1, 1998. }\end{array}$ & Gautam Ahuja and Sumit K. Majumdar & April 1997 \\
\hline $\begin{array}{l}\text { No. 64: Published in: Journal of Law and } \\
\text { Economics, "Foreign Ownership and } \\
\text { Profitability: Property Rights, Control and the } \\
\text { Performance of Firms in Indian Industry" } \\
\text { 42(1), April 1999, pp. 209-38. }\end{array}$ & $\begin{array}{l}\text { Pradeep K. Chhibber and Sumit K. } \\
\text { Majumdar }\end{array}$ & April 1997 \\
\hline $\begin{array}{l}\text { No. 63: How Taxing Is Corruption on } \\
\text { International Investors? }\end{array}$ & Shang-Jin Wei & February 1997 \\
\hline $\begin{array}{l}\text { No. 62: What Can We Learn from the } \\
\text { Experience of Transitional Economies with }\end{array}$ & Tito Boeri & 1997 \\
\hline
\end{tabular}

Working Papers are available at:

www.wdi.bus.umich.edu 


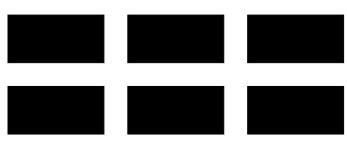

THE WILLIAM DAVIDSON INSTITUTE

AT THE UNIVERSITY OF MICHIGAN BUSINESSSCHOOL

\begin{tabular}{|c|c|c|}
\hline Labour Market Policies? & & \\
\hline $\begin{array}{l}\text { No. 61: Published in: Accounting } \\
\text { Organizations and Society, "Economic } \\
\text { Transition, Strategy and the Evolution of } \\
\text { Management Accounting Practices: The Case } \\
\text { of India" 24(5,6), Jul/Aug 1999, pp. 379-412. }\end{array}$ & $\begin{array}{l}\text { Shannon W. Anderson and William N. } \\
\text { Lanen }\end{array}$ & April 1997 \\
\hline $\begin{array}{l}\text { No. 60a: Enterprise Investment During the } \\
\text { Transition: Evidence from Czech Panel Data }\end{array}$ & Lubomír Lizal and Jan Svejnar & December 1997 \\
\hline $\begin{array}{l}\text { No. 59: Published in: Journal of Law, } \\
\text { Economics, and Organization, "Institutional } \\
\text { Environment, Community Government, and } \\
\text { Corporate Governance: Understanding } \\
\text { China's Township-Village Enterprises." } \\
\text { 14(1), April 1998, pages 1-23 }\end{array}$ & Jiahua Che and Yingyi Qian & April 1997 \\
\hline $\begin{array}{l}\text { No. 58: From the Grabbing Hand to the } \\
\text { Helping Hand }\end{array}$ & Jiahua Che & June 2000 \\
\hline $\begin{array}{l}\text { No. 57: Published in: Brookings Papers on } \\
\text { Economic Activity, "The Unofficial Economy } \\
\text { in Transition." 1: 1998. }\end{array}$ & $\begin{array}{l}\text { Simon Johnson, Daniel Kaufmann, and } \\
\text { Andrei Schleifer }\end{array}$ & June 1997 \\
\hline $\begin{array}{l}\text { No. 56: Taxes and Government Incentives: } \\
\text { Eastern Europe vs. China }\end{array}$ & Roger H. Gordon and David D. Li & April 1997 \\
\hline No. 55: Corruption and Reform & Susanto Basu and David Li & June 1996 \\
\hline $\begin{array}{l}\text { No. 54: Decentralization and the } \\
\text { Macroeconomic Consequences of } \\
\text { Commitment to State-Owned Firms }\end{array}$ & Loren Brandt and Xiaodong Zhu & June 1997 \\
\hline $\begin{array}{l}\text { No. 53: Published in: The International } \\
\text { Journal of Industrial Organization, } \\
\text { "Competitive Shocks and Industrial Structure: } \\
\text { The Case of Polish Manufacturing." August, } \\
\text { 1999. . }\end{array}$ & Pankaj Ghemawat and Robert E. Kennedy & May 1997 \\
\hline $\begin{array}{l}\text { No. 52: Published in: The Quarterly Journal } \\
\text { of Economics, "Insecure Property Rights and } \\
\text { Government Ownership of Firms." May, } \\
\text { 1998. }\end{array}$ & Jiahua Che and Yingyi Qian & May 1997 \\
\hline $\begin{array}{l}\text { No. 51: Incentives, Scale Economies, and } \\
\text { Organizational Form }\end{array}$ & $\begin{array}{l}\text { Eric Maskin, Yingyi Qian, and Chenggang } \\
X u\end{array}$ & May 1997 \\
\hline $\begin{array}{l}\text { No. 50: Published in: Post-Soviet-Affairs, } \\
\text { "End of the Tunnel? The Effects of Financial } \\
\text { Stabilization in Russia" April-June 1997, } \\
\text { pages 105-33 }\end{array}$ & $\begin{array}{l}\text { Barry W. Ickes, Peter Murrell, and Randi } \\
\text { Ryterman }\end{array}$ & March 1997 \\
\hline $\begin{array}{l}\text { No. 49: The Evolution of Bank Credit Quality } \\
\text { in Transition: Theory and Evidence from } \\
\text { Romania }\end{array}$ & Enrico C. Perotti and Octavian Carare & October 1996 \\
\hline $\begin{array}{l}\text { No. 48: Where Do the Leaders Trade? } \\
\text { Information Revelation and Interactions } \\
\text { Between the Segments of Czech Capital } \\
\text { Markets }\end{array}$ & Jan Hanousek and Libor Nemecek & May 1997 \\
\hline $\begin{array}{l}\text { No. 47: Firms' Heterogeneity in Transition: } \\
\text { Evidence from a Polish Panel Data Set }\end{array}$ & Irena Grosfeld and Jean-François Nivet & May 1997 \\
\hline $\begin{array}{l}\text { No. 46: Strategic Creditor Passivity, } \\
\text { Regulation, and Bank Bailouts }\end{array}$ & Janet Mitchell & May 1997 \\
\hline No. 45a: Published in: Journal of Public & Daniel M. Berkowitz and Wei Li & September 1997 \\
\hline
\end{tabular}

Working Papers are available at:

www.wdi.bus.umich.edu 


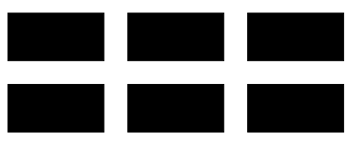

THE WILLIAM DAVIDSON INSTITUTE

AT THE UNIVERSITY OF MICHIGAN BUSINESSSCHOOL

\begin{tabular}{|c|c|c|}
\hline $\begin{array}{l}\text { Economics, "Tax Rights in Transition } \\
\text { Economies: A Tragedy of the Commons." 76, } \\
\text { 2000, pp. 369-397 }\end{array}$ & & \\
\hline $\begin{array}{l}\text { No. 44a: The Information Content of Stock } \\
\text { Markets: Why do Emerging Markets have } \\
\text { Synchronous Stock Price Movements? } \\
\text { (forthcoming in the Journal of Financial } \\
\text { Economics). }\end{array}$ & $\begin{array}{l}\text { Randall Morck, Bernard Yeung, and } \\
\text { Wayne Yu }\end{array}$ & February 1999 \\
\hline $\begin{array}{l}\text { No. 43: Agency in Project Screening and } \\
\text { Termination Decisions: Why Is Good Money } \\
\text { Thrown After Bad? }\end{array}$ & Chong-en Bai and Yijiang Wang & May 1997 \\
\hline $\begin{array}{l}\text { No. 42: Published in: Economics of } \\
\text { Transition, "Channels of Redistribution: } \\
\text { Inequality and Poverty in the Russian } \\
\text { Transition." Vol. } 7 \text { (2) } 1999 .\end{array}$ & $\begin{array}{l}\text { Simon Commander, Andrei Tolstopiatenko, } \\
\text { and Ruslan Yemtsov }\end{array}$ & May 1997 \\
\hline $\begin{array}{l}\text { No. 41: Published in: Economics of } \\
\text { Transition, "Labour Market Characteristics } \\
\text { and Profitability: Econometric Analysis of } \\
\text { Hungarian Exporting Firms, 1986-1995" } \\
\text { 6(1), May 1998, pages 145-62 }\end{array}$ & László Halpern and Gabor Korosi & May 1997 \\
\hline $\begin{array}{l}\text { No. 40: Published in: the Harvard Law } \\
\text { Review, "The Tragedy of the Anticommons: } \\
\text { Property in the Transition from Marx to } \\
\text { Markets." January 1998. }\end{array}$ & Michael Heller & February 1997 \\
\hline $\begin{array}{l}\text { No. 39: Privatization and Managerial } \\
\text { Efficiency }\end{array}$ & Olivier Debande and Guido Friebel & May 1997 \\
\hline $\begin{array}{l}\text { No. } 38 \text { Published in: The Quarterly Journal } \\
\text { of Economics, "Disorganization." Vol. 112, } \\
\text { No. 4, November 1997, pp. 1091-1126. }\end{array}$ & Olivier Blanchard and Michael Kremer & January 1997 \\
\hline $\begin{array}{l}\text { No. 37: Published in: Economics of } \\
\text { Transition, "Transition and the Output Fall." } \\
\text { 7(1), 1999, pages 1-28. }\end{array}$ & Gérard Roland and Thierry Verdier & March 1997 \\
\hline $\begin{array}{l}\text { No. 36: Restructuring an Industry During } \\
\text { Transition: A Two-Period Model }\end{array}$ & Richard Ericson & September 1996 \\
\hline $\begin{array}{l}\text { No. 34: The East-West Joint Venture: } B C \\
\text { Torsion Case Study }\end{array}$ & Sonia Ferencikova and Vern Terpstra & December 1998 \\
\hline $\begin{array}{l}\text { No. } 33 \text { Published in: Journal of Comparative } \\
\text { Economics, "Quantifying Price Liberalization } \\
\text { in Russia." Vol. 26, No. 4, December 1998, } \\
\text { pp. } 735-737 .\end{array}$ & $\begin{array}{l}\text { Daniel Berkowitz, David DeJong, and } \\
\text { Steven Husted }\end{array}$ & December 1998 \\
\hline $\begin{array}{l}\text { No. 32: What Can North Korea Learn from } \\
\text { China's Market Reforms? }\end{array}$ & John McMillan & September 1996 \\
\hline $\begin{array}{l}\text { No. 31: Published in: China-Economic- } \\
\text { Review, “Towards a Model of China as a } \\
\text { Partially Reformed Developing Economy } \\
\text { Under a Semifederalist Government.", 9(1), } \\
\text { Spring 1998, pages 1-23. }\end{array}$ & Yijiang Wang and Chun Chang & March 1997 \\
\hline $\begin{array}{l}\text { No. 30: Convergence in Output in Transition } \\
\text { Economies: Central and Eastern Europe, } \\
\text { 1970-1995 }\end{array}$ & Saul Estrin and Giovanni Urga & February 1997 \\
\hline $\begin{array}{l}\text { No. 29: Published in: Economics of } \\
\text { Transition, "Altered Band and Exchange }\end{array}$ & Evzen Kocenda & March 1997 \\
\hline
\end{tabular}

Working Papers are available at:

www.wdi.bus.umich.edu 


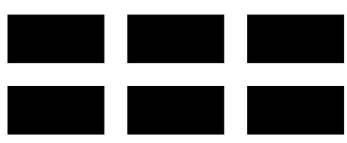

THE WILLIAM DAVIDSON INSTITUTE

AT THE UNIVERSITY OF MICHIGAN BUSINESSSCHOOL

\begin{tabular}{|c|c|c|}
\hline Volatility." Volume 6, no. 1, 1998, 173-181. & & \\
\hline $\begin{array}{l}\text { No. 28: Published in: Quarterly Journal of } \\
\text { Economics, "Public Versus Private } \\
\text { Ownership of Firms: Evidence from Rural } \\
\text { China." Volume 113, no. 3, August 1998, 773- } \\
808 .\end{array}$ & Hehui Jin and Yingyi Qian & January 1997 \\
\hline $\begin{array}{l}\text { No. 27: East-West Joint Ventures in a } \\
\text { Transitional Economy: The Case of Slovakia }\end{array}$ & Sonia Ferencikova & March 1997 \\
\hline $\begin{array}{l}\text { No. 26: Published in Economic Analysis } \\
\text { "Behavior of a Slovenian Firm in Transition" } \\
\text { Vol. } 1, \text { no. } 1,1998,57-73 .\end{array}$ & Janez Prasnikar & February 1997 \\
\hline $\begin{array}{l}\text { No. 25: Cultural Encounters and Claims to } \\
\text { Expertise in Postcommunist Capitalism }\end{array}$ & Michael D. Kennedy & February 1997 \\
\hline $\begin{array}{l}\text { No. 24: ZVU a.s.: Investment Funds on the } \\
\text { Board of Directors of an Engineering Giant }\end{array}$ & Tory Wolff & August 1995 \\
\hline $\begin{array}{l}\text { No. 23: The Role of Investment Funds in the } \\
\text { Czech Republic (joint publication with Czech } \\
\text { Management Center) }\end{array}$ & Dusan Triska & June 1996 \\
\hline $\begin{array}{l}\text { No. 22: Czech Investment Fund Industry: } \\
\text { Development and Behaviour (joint publication } \\
\text { with Czech Management Center) }\end{array}$ & Richard Podpiera & May 1996 \\
\hline $\begin{array}{l}\text { No. 21: Restructuring of Czech Firms: An } \\
\text { Example of Gama, a.s. (joint publication with } \\
\text { Czech Management Center) }\end{array}$ & Antonin Bulin & June 1996 \\
\hline $\begin{array}{l}\text { No. 20: YSE Funds: A Story of Czech } \\
\text { Investment Funds (joint publication with } \\
\text { Czech Management Center) }\end{array}$ & Michal Otradovec & November 1995 \\
\hline $\begin{array}{l}\text { No. 19: Prvni Investicni a.s., The First } \\
\text { Investment Corporation (joint publication } \\
\text { with Czech Management Center) }\end{array}$ & Jaroslav Jirasek & August 1995 \\
\hline $\begin{array}{l}\text { No. 18: PPF a.s., The First Private Investment } \\
\text { Fund (joint publication with Czech } \\
\text { Management Center) }\end{array}$ & Michal Otradovec & November 1995 \\
\hline $\begin{array}{l}\text { No. } 17 \text { Published in: Post-Soviet Geography } \\
\text { and Economics, "Russia's Managers in } \\
\text { Transition: Pilferers or Paladins?" Vol. 37, } \\
\text { o.7 (September 1996), pp. 397-426. }\end{array}$ & Susan J. Linz and Gary Krueger & November 1996 \\
\hline $\begin{array}{l}\text { No. 16: Banks in Transition-Investment } \\
\text { Opportunities in Central Europe and Russia } \\
\text { Edited Transcript from } 31 \text { May } 1996 \\
\text { Conference in New York City }\end{array}$ & $\begin{array}{l}\text { With commentary and edited by Anna } \\
\text { Meyendorff }\end{array}$ & January 1997 \\
\hline $\begin{array}{l}\text { No. 15: Marketing in Transitional Economies: } \\
\text { Edited Transcript \& Papers from } 1 \text { April } 1996 \\
\text { Conference in Ann Arbor, Michigan }\end{array}$ & Compiled by The Davidson Institute & December 1996 \\
\hline $\begin{array}{l}\text { No. 14: Pensions in the Former Soviet Bloc: } \\
\text { Problems and Solutions. Published by } \\
\text { Council on Foreign Relations. "The Coming } \\
\text { Global Pension Crisis" New York, } 1997\end{array}$ & Jan Svejnar & November 1996 \\
\hline $\begin{array}{l}\text { No. 13: Enterprise Restructuring and } \\
\text { Performance in the Transition. Forthcoming } \\
\text { in Financial Systems in Transition: The } \\
\text { Design of Financial Systems in Central }\end{array}$ & $\begin{array}{l}\text { Lubomir Lizal, Miroslav Singer, and Jan } \\
\text { Svejnar }\end{array}$ & December 1996 \\
\hline
\end{tabular}

Working Papers are available at:

www.wdi.bus.umich.edu 


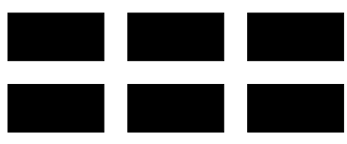

THE WILLIAM DAVIDSON INSTITUTE

AT THE UNIVERSITY OF MICHIGAN BUSINESSSCHOOL

\begin{tabular}{|c|c|c|}
\hline $\begin{array}{l}\text { Europe eds. Anna Meyendorff and Anjan } \\
\text { Thakor. }\end{array}$ & & \\
\hline $\begin{array}{l}\text { No. } 12 \text { Published in: Journal of International } \\
\text { Marketing, "Executive Insights: Marketing } \\
\text { Issues and Challenges in Transitional } \\
\text { Economies." Vol. 5, No. 4, 1997, pp. 95-114. } \\
\text { Also published in: Marketing Issues in } \\
\text { Transitional Economies ed. Rajeev Batra. }\end{array}$ & Rajeev Batra & April 1997 \\
\hline $\begin{array}{l}\text { No. 11: Worker Trust and System } \\
\text { Vulnerability in the Transition from Socialism } \\
\text { to Capitalism }\end{array}$ & Andrew Schotter & August 1996 \\
\hline $\begin{array}{l}\text { No. } 10 \text { Published in: Comparative Economic } \\
\text { Studies, "Russian Firms in Transition: } \\
\text { Champions, Challengers, and Chaff." Vol. } \\
\text { 39, No.2, Summer 1997, pp. 1-36. }\end{array}$ & Susan J. Linz & July 1996 \\
\hline $\begin{array}{l}\text { No. 9: Corporate Debt Crisis and Bankruptcy } \\
\text { Law During the Transition: The Case of China }\end{array}$ & David D. Li and Shan Li & December 1995 \\
\hline $\begin{array}{l}\text { No. } 8 \text { Published in: Journal of Comparative } \\
\text { Economics, "A Theory of Ambiguous } \\
\text { Property Rights in Transition Economies: The } \\
\text { Case of the Chinese Non-State Sector." Vol. } \\
\text { 23, No. 1, August 1996, pp. 1-19. }\end{array}$ & David D. Li & June 1996 \\
\hline $\begin{array}{l}\text { No. 7: The Foreign Economic Contract Law of } \\
\text { China: Cases and Analysis }\end{array}$ & Dong-lai Li & June 1993 \\
\hline $\begin{array}{l}\text { No. 3: Bank Privatization in Hungary and the } \\
\text { Magyar Kulkereskedelmi Bank Transaction }\end{array}$ & Roger Kormendi and Karen Schnatterly & May 1996 \\
\hline $\begin{array}{l}\text { Replacing Nos. 1-2 \& 4-6: Journal of } \\
\text { Comparative Economics Symposium on } \\
\text { "Bank Privatization in Central Europe and } \\
\text { Russia." Vol. 25, No. 1, August 1997. }\end{array}$ & $\begin{array}{l}\text { No. } 1 \text { "Bank Privatization in Transitional } \\
\text { Economies" by Roger Kormendi and } \\
\text { Edward Snyder. No. } 2 \text { "Transactional } \\
\text { Structures of Bank Privatizations in } \\
\text { Central Europe and Russia” by Anna } \\
\text { Meyendorff and Edward A. Snyder. No. } 4 \\
\text { "Bank Privatization in Poland: The Case } \\
\text { of Bank Slaski” by Jeffery Abarbaness and } \\
\text { John Bonin. No. } 5 \text { "Bank Privatization in } \\
\text { Post-Communist Russia: The Case of } \\
\text { Zhilsotsbank" by Jeffery Abarbanell and } \\
\text { Anna Meyendorff and No. } 6 \text { "”"The Czech } \\
\text { Republic's Commercial Bank: Komercni } \\
\text { Banka" by Edward A. Snyder and Roger } \\
\text { C. Kormendi. }\end{array}$ & August 1997 \\
\hline
\end{tabular}

Working Papers are available at:

www.wdi.bus.umich.edu 